\title{
Epigenetics of human cutaneous melanoma: setting the stage for new therapeutic strategies
}

\author{
Luca Sigalotti*1, Alessia Covre1,2, Elisabetta Fratta1', Giulia Parisi1,2, Francesca Colizzi1', Aurora Rizzo'1, Riccardo Danielli², \\ Hugues JM Nicolay², Sandra Coral' ${ }^{1}$ and Michele Maio ${ }^{1,2}$
}

\begin{abstract}
Cutaneous melanoma is a very aggressive neoplasia of melanocytic origin with constantly growing incidence and mortality rates world-wide. Epigenetic modifications (i.e., alterations of genomic DNA methylation patterns, of posttranslational modifications of histones, and of microRNA profiles) have been recently identified as playing an important role in melanoma development and progression by affecting key cellular pathways such as cell cycle regulation, cell signalling, differentiation, DNA repair, apoptosis, invasion and immune recognition. In this scenario, pharmacologic inhibition of DNA methyltransferases and/or of histone deacetylases were demonstrated to efficiently restore the expression of aberrantly-silenced genes, thus re-establishing pathway functions. In light of the pleiotropic activities of epigenetic drugs, their use alone or in combination therapies is being strongly suggested, and a particular clinical benefit might be expected from their synergistic activities with chemo-, radio-, and immuno-therapeutic approaches in melanoma patients. On this path, an important improvement would possibly derive from the development of new generation epigenetic drugs characterized by much reduced systemic toxicities, higher bioavailability, and more specific epigenetic effects.
\end{abstract}

\section{Introduction}

Cutaneous melanoma $(\mathrm{CM})$ is a highly aggressive malignancy originating from melanocytes, which is characterized by constantly growing incidence and mortality rates world-wide [1]. Unlike the majority of human cancers, $\mathrm{CM}$ is frequently diagnosed in young and middle-aged adults [2]. Despite representing only $3 \%$ of all skin malignancies, $\mathrm{CM}$ is responsible for $65 \%$ of skin malignancyrelated deaths, and the 5-year survival of metastatic CM patients is $7-19 \%[3,4]$.

The increasing incidence and the poor prognosis of $\mathrm{CM}$, along with the substantial unresponsiveness of advanced disease to conventional therapies, have prompted significant efforts in defining the molecular alterations that accompany the malignant transformation of melanocytes, identifying epigenetic modifications as important players [5]. "Epigenetics" refers to heritable alterations in gene expression that are not achieved through changes in the primary sequence of genomic DNA. In this respect, the most extensively characterized

\footnotetext{
* Correspondence: Isigalotti@cro.it
}

${ }^{1}$ Cancer Bioimmunotherapy Unit, Centro di Riferimento Oncologico, Istituto di Ricovero e Cura a Carattere Scientifico, Via F. Gallini 2, 33081 Aviano, Italy Full list of author information is available at the end of the article mediators of epigenetic inheritance are the methylation of genomic DNA in the context of CpG dinucleotides, and the post-translational modifications of core histone proteins involved in the packing of DNA into chromatin [6]. Despite not yet having been extensively characterized, also microRNAs (miRNAs) are emerging as important factors in epigenetic determination of gene expression fate in CM [7].

DNA methylation occurs at the $\mathrm{C} 5$ position of cytosine in the context of $\mathrm{CpG}$ dinucleotides and it is carried out by different DNA methyltransferases (DNMT) that have distinct substrate specificities: DNMT1 preferentially methylates hemimethylated DNA and has been associated with the maintenance of DNA methylation patterns [8]; DNMT3a and 3b do not show preference for hemimethylated DNA and have been implicated in the generation of new methylation patterns $[9,10]$. Besides this initial strict categorization, recent evidences are indicating that all three DNMTs may possess both de novo and maintenance functions in vivo, and that they cooperate in establishing and maintaining DNA methylation patterns [11-14]. The methylation of promoter regions inhibits gene expression either by directly blocking the binding of 
transcriptional activators or by binding methyl-CpGbinding domain (MBD) proteins that silence gene expression through the recruitment of chromatin remodeling co-repressor complexes (Figure 1) $[15,16]$.

Genomic DNA in the nucleus is packed into the chromatin, the base unit of which is the nucleosome: a histone octamer core comprising two copies each of histones $\mathrm{H} 2 \mathrm{~A}, \mathrm{H} 2 \mathrm{~B}, \mathrm{H} 3$ and $\mathrm{H} 4$, around which about $147 \mathrm{bp}$ of DNA are wrapped. Each histone contains flexible N-terminal tails protruding from the nucleosomes, which are extensively targeted by post-translational modifications, including acetylation and methylation. These modifications determine how tightly the chromatin is compacted, thus playing a central regulatory role in gene expression. The acetylation status of histones is controlled by the balanced action of histone acetyltransferases and histone deacetylases (HDAC), and acetylated histones have been associated with actively expressed genes. On the other hand, methylation of histones, accomplished by histone methyl transferases (HMT), may have both repressive (H3 lysine (K) 9, H3K27) or promoting (H3K4) effects on transcription, depending on the target residue (Figure 1) [17]. Histone modifications comprehensively define the so called "histone code" that is read by multi-protein chromatin remodelling complexes to finally determine the transcriptional status of the target gene by modulating chromatin compaction grade [18].

MiRNAs, the most recently discovered mediators of epigenetic gene regulation, are endogenous non-coding RNA about 22 nucleotide long. MiRNAs are transcribed in the nucleus by RNA polymerase II into long primary transcripts (pri-miRNAs), which are further processed by a complex of the RNase III Drosha and its cofactor DGCR8 into the about 60 nucleotides long precursor miRNAs (pre-miRNAs). Pre-miRNAs are subsequently exported to the cytoplasm where the RNase III Dicer cuts off the loop portion of the stem-loop structure, thus reducing pre-miRNAs to short double strands. Finally, each pre-miRNA is unwound by a helicase into the functional miRNA. Once incorporated into the RNA-induced silencing complex, miRNAs recognize their target mRNA through a perfect or nearly perfect sequence complementarity, and direct their endonucleolytic cleavage or inhibit their translation (Figure 1). Each miRNA is predicted to have many targets, and each mRNA may be regulated by more than one miRNA [7].

Rather than acting separately, the above described epigenetic regulators just represent different facets of an integrated apparatus of epigenetic gene regulation (Figure 1). Indeed, recent studies showed that DNA methylation affects histone modifications and vice versa, to make up a highly complex epigenetic control mechanism that cooperates and interacts in establishing and maintaining the patterns of gene expression [19]. Along this line, miRNA were demonstrated to be target of regulation by DNA methylation, while concomitantly being able to regulate the expression of different chromatin-modifying enzymes [7].

\section{Identifying epigenetic alterations in CM}

The maintenance of epigenetic marks, either natural or acquired through neoplastic transformation, requires the function of specific enzymes, such as DNMT and HDAC. The pharmacologic and/or genetic inactivation of DNMT and/or HDAC erases these epigenetic marks, leading to the reactivation of epigenetically-silenced genes [20]. This pharmacologic reversal has been widely exploited to identify genes and cellular pathways that were potentially inactivated by aberrant epigenetic alterations in $\mathrm{CM}$ $[21,22]$ : genes down-regulated in $\mathrm{CM}$ as compared to melanocytes, and whose expression was induced/up-regulated by epigenetic drugs, were assumed to be epigenetically inactivated in CM. Gene expression microarrays were recently used to assess the modulation of the whole transcriptome by the DNMT inhibitor 5-aza-2'-deoxycytidine (5-AZA-CdR) in different CM cell lines, allowing to identify a large number of genes that were potentially inactivated by promoter methylation in CM, as further supported by preliminary methylation analyses performed on $20 \mathrm{CM}$ tissues [21]. A similar approach investigated genome-wide gene re-expression/up-regulation following combined treatment with 5-AZA-CdR and the HDAC inhibitor (HDACi) Trichostatin A (TSA), to identify genes suppressed in CM cells by aberrant promoter hypermethylation and histone hypoacetylation [22]. Despite the power of these approaches, care must be taken to correctly interpret these high-throughput results [23]: an adequate statistical treatment of data is mandatory to obtain robust findings, which are finally required to be validated through the direct evaluation of the correlation between promoter methylation or histone posttranslational modifications and the expression of the identified genes, in large cohorts of CM lesions. Along this line, the specific functional role of each of these genes in CM biology is being further examined either by gene transfer or RNA interference approaches in CM cell lines [21].

The direct evaluation of the DNA methylation status of the genes of interest is performed through different technologies that usually rely on the modification of genomic DNA with sodium bisulfite, which converts unmethylated, but not methylated, cytosines to uracil, allowing methylation data to be read as sequence data $[24,25]$. The most widely used bisulfite-based methylation assays are: i) bisulfite sequencing [25]; ii) bisulfite pyrosequencing [26]; iii) Combined Bisulfite Restriction Analysis (CoBRA) [27]; iv) Methylation-Specific PCR (MSP) [28]; v) MSP real-time PCR [29]. Global genomic DNA methy- 


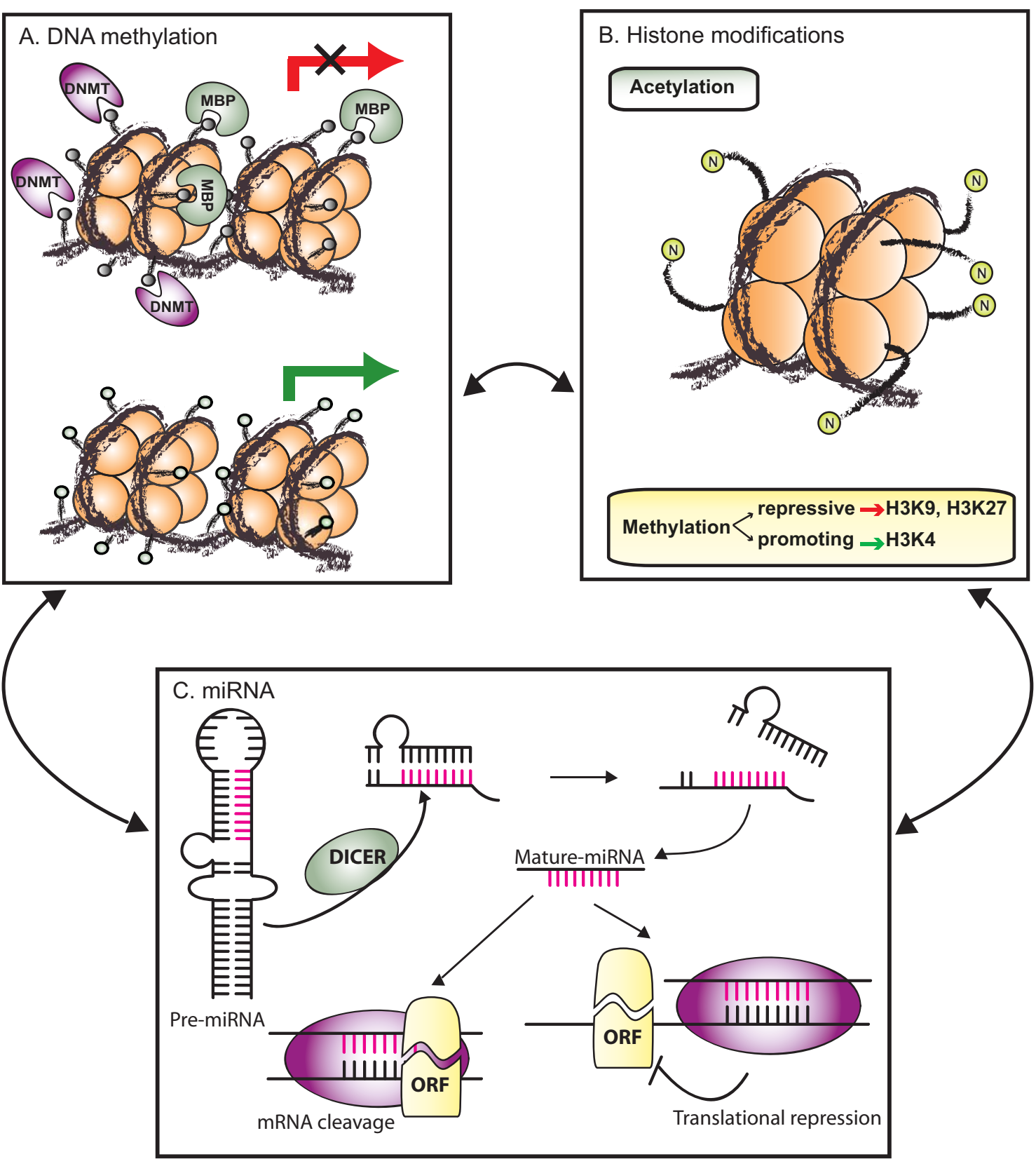

Figure 1 Epigenetic alterations in CM. Epigenetic regulation of gene expression involves the interplay of DNA methylation, histone modifications and miRNAs. A. Transcriptionally inactive genes (crossed red arrow) are characterized by the presence of methylated cytosines within CpG dinucleotides (grey circles), which is carried out and sustained by DNA methyltransferases (DNMT). Transcriptional repression may directly derive from methylated recognition sequence preventing the binding of transcription factors, or may be a consequence of the binding of methyl-CpG-binding proteins (MBP), which recruit chromatin remodelling co-repressor complexes. Transcriptionally active genes (green arrow) contain demethylated CpG dinucleotides (green circles), which prevent the binding of MBP and co-repressor complexes, and are occupied by complexes including transcription factors and co-activators. B. Histones are subjected to a variety of post-translational modifications on their amino terminus ( $\mathrm{N}$ ), including methylation and acetylation, which determine chromatin structure, resulting in the modulation of accessibility of DNA for the transcriptional machinery. The acetylation status of histones is controlled by the balanced action of histone acetyltransferases and histone deacetylases, and acetylated histones have been associated with actively expressed genes. Histone methylation may have both repressive (H3K9, H3K27) or promoting (H3K4) effects on transcription, depending on which residue is modified. C. MiRNAs are small non-coding RNAs that regulate the expression of complementary mRNAs. Once incorporated into the RNA-induced silencing complex, miRNAs recognize their target mRNA through a perfect or nearly perfect sequence complementarity, and direct their endonucleolytic cleavage or inhibit their translation. DICER, RNase III family endoribonuclease, ORF, open reading frame. 
lation assays may be used to directly assess the overall role of aberrant DNA methylation in CM biology, and include: i) methylation of the repetitive elements LINE-1 and $A l u$ by CoBRA or pyrosequencing [30]; ii) 5 -methylcytosine content by HPLC or capillary electrophoresis [31]; iii) whole genome evaluation of CpG island methylation by $\mathrm{CpG}$ island microarrays [32]. Along this line, a genome-wide integrative analysis of promoter methylation and gene expression microarray data might assist in the identification of methylation markers that are likely to have a biologic relevance due to their association with altered levels of expression of the respective gene [32]. The bias posed by the pre-definition of the sequences to be investigated, which is inherently associated with $\mathrm{CpG}$ island microarray analyses, will be most likely overcome in the next few years by exploiting the next-generation sequencing technologies [33]. The application of these approaches on genomic DNA that has been enriched in methylated sequences by affinity chromatography, with either anti-5-methyl-cytosine antibodies or MBD proteins, can be expected to provide a detailed and essentially unbiased map of the whole methylome of CM.

On the other hand, global levels of histone modifications can be evaluated through either mass spectrometry or Western blot analysis [34]. The direct evaluation of gene-associated histone post-translational modifications relies on immunoprecipitation of chromatin with antibodies specifically recognizing histones with modified tails, followed by PCR amplification of the gene of interest. This immunoprecipitation approach might be eventually coupled to genomic microarray hybridization or next-generation sequencing to examine at whole genome level the aberrant genetic patterns of histone post-translational modifications [35].

\section{DNA methylation}

Neoplastic transformation is accompanied by a complex deregulation of the cellular DNA methylation homeostasis, resulting in both gene-specific hypermethylation and genome-wide hypomethylation [6].

Aberrant DNA hypermethylation is a frequent event in $\mathrm{CM}$ and represents an important mechanism utilized by neoplastic cells to shut off different tumor suppressor genes (TSG) (Figure 2, Table 1). Inactivation by DNA hypermethylation was found to affect also genes that are not typically targeted by gene deletion/mutation, providing complementary tools for melanocyte transformation. Nevertheless, genetic and epigenetic alterations also cooperate to shut off specific gene functions, as it was seen for the CDKN2A locus [36,37]. CDKN2A can be regarded as the major gene involved in $\mathrm{CM}$ pathogenesis and predisposition, being inactivated in the majority of sporadic $\mathrm{CM}$ and representing the most frequently mutated gene inherited in familial CM [38]. CDKN2A locus encodes two proteins, p16 $16^{\mathrm{NK} 4 \mathrm{~A}}$ and $\mathrm{p} 14^{\mathrm{ARF}}$, which exert tumor suppressor functions through the pRB and the p53 pathways, respectively [38]. Recent data have demonstrated that aberrant promoter hypermethylation at $C D K N 2 A$ locus independently affects $\mathrm{p} 16^{\mathrm{INK} 4 \mathrm{~A}}$ and $\mathrm{p} 14^{\mathrm{ARF}}$, which are methylated in $27 \%$ and $57 \%$ of metastatic CM samples, respectively [37]. These epigenetic alterations had an incidence comparable to gene deletions/mutations, and frequently synergized with them to achieve a complete loss of TSG expression: gene deletion eliminating one allele, promoter hypermethylation silencing the remaining one. This combined targeting of the CDKN2A locus, through epigenetic and genetic alterations, led to the concomitant inactivation of both $\mathrm{p} 16^{\mathrm{INK}} 4 \mathrm{~A}$ and $\mathrm{p} 14 \mathrm{ARF}$ in a significant proportion of metastatic CM examined, likely allowing neoplastic cells to evade the growth arrest, apoptosis and senescence programs triggered by the pRB and p53 pathways. Besides specific examples, on the whole, gene-specific hypermethylation has been demonstrated to silence genes involved in all of the key pathways of CM development and progression, including cell cycle regulation, cell signalling, differentiation, DNA repair, apoptosis, invasion and immune recognition (Figure 2, Table 1). RAR- $\beta 2$, which mediates growth arrest, differentiation and apoptotic signals triggered by retinoic acids (RA), together with RASSF1A, which promotes apoptosis and growth arrest, and $M G M T$, which is involved in DNA repair, are the most frequent and well-characterized hypermethylated genes in CM, being methylated in 70\% [39], 55\% [40,41] and 34\% of CM lesions, respectively [39] (Figure 2, Table 1). Notably, a very high incidence of promoter methylation has been observed for genes involved in the metabolic activation of chemotherapeutic drugs (i.e., $C Y P 1 B 1$, methylated in $100 \% \mathrm{CM}$ lesions [21], and DNAJC15, methylated in 50\% CM lesions [21]), which might contribute, together with the impairment of the apoptotic pathways, to the well-known resistance of CM cells to conventional chemotherapy. The list of genes hypermethylated in CM is continuously expanding, and it is including new genes that are hypermethylated in virtually all CM lesions examined (e.g., QPCT, methylated in $100 \%$ CM [21]; LXN, methylated in 95\% CM [21]), though their function/role in CM progression has still to be addressed. Interestingly, some genes, such as $R A R-\beta 2$, are found methylated with similar frequencies in primary and metastatic $\mathrm{CM}$, suggesting their methylation as being an early event in $C M$, while others have higher frequencies in advanced disease (e.g., MGMT, RASSF1A, DAPK), suggesting the implication of their aberrant hypermethylation in CM progression [39]. Along this line, a recent paper by Tanemura et al reported the presence of a CpG island methylator phenotype (i.e., high incidence of concomitant methylation of different CpG islands) in CM, which was associated with advancing clinical tumor 
Table 1: Genes with an altered DNA methylation status in human CM

\begin{tabular}{|c|c|c|c|c|c|c|c|}
\hline PATHWAY & GENE & $\begin{array}{l}\text { METHYLATION } \\
\text { STATUS IN CMa }\end{array}$ & PERCENT & FREQUENCY & SOURCE & $\begin{array}{l}\text { MODULATED } \\
\text { BY 5-AZA-CdR }\end{array}$ & REF. \\
\hline \multirow[t]{21}{*}{ APOPTOSIS } & $D A P K b$ & methylated & 19 & $16 / 86$ & tumor & $N^{c}$ & [39] \\
\hline & HSPB6 & methylated & 100 & $8 / 8$ & cell line & YES & [32] \\
\hline & HSPB8 & methylated & 69 & $11 / 16$ & tumor & YES & [128] \\
\hline & RASSF1A & methylated & NA & NA & cell line & YES & [41] \\
\hline & & methylated & 46 & $6 / 13$ & cell line & YES & [129] \\
\hline & & methylated & 69 & $11 / 16$ & cell line & ND & [44] \\
\hline & & methylated & 63 & $26 / 41$ & serum & NA & [130] \\
\hline & & methylated & 28 & $13 / 47$ & serum & NA & [124] \\
\hline & & methylated & 19 & $6 / 31$ & serum & NA & [39] \\
\hline & & methylated & 25 & $10 / 40$ & tumor & ND & [101] \\
\hline & & methylated & 36 & $9 / 24$ & tumor & NA & [129] \\
\hline & & methylated & 55 & $24 / 44$ & tumor & YES & [40] \\
\hline & & methylated & 57 & $49 / 86$ & tumor & YES & [39] \\
\hline & TMS1 & methylated & 8 & $3 / 40$ & tumor & ND & [101] \\
\hline & & methylated & 50 & $5 / 10$ & tumor & YES & [131] \\
\hline & TNFRSF10C & methylated & 57 & $23 / 40$ & tumor & YES & [101] \\
\hline & TNFRSF10D & methylated & 80 & $32 / 40$ & tumor & YES & [101] \\
\hline & TP53INP1 & methylated & 19 & $3 / 16$ & tumor & YES & [22] \\
\hline & TRAILR1 & methylated & 80 & $8 / 10$ & cell line & YES & [98] \\
\hline & & methylated & 13 & $5 / 40$ & tumor & ND & [101] \\
\hline & XAF1 & methylated & NA & NA & cell line & YES & [99] \\
\hline $\begin{array}{l}\text { ANCHORAGE } \\
\text { INDEPENDEN }\end{array}$ & TPM1 & methylated & 8 & $3 / 40$ & tumor & ND & [101] \\
\hline
\end{tabular}

\begin{tabular}{|c|c|c|c|c|c|c|c|}
\hline \multirow[t]{10}{*}{ CELL CYCLE } & CDKN1B & methylated & 0 & $0 / 13$ & cell line & ND & [129] \\
\hline & & methylated & 0 & $0 / 40$ & tumor & ND & [101] \\
\hline & & methylated & 9 & $4 / 45$ & tumor & ND & [132] \\
\hline & CDKN1C & methylated & 35 & $7 / 20$ & tumor & YES & [21] \\
\hline & CDKN2A & methylated & 76 & $31 / 41$ & serum & NA & [130] \\
\hline & & methylated & 10 & $3 / 30$ & tumor & YES & [36] \\
\hline & & methylated & 13 & $5 / 40$ & tumor & ND & [101] \\
\hline & & methylated & 19 & $11 / 59$ & tumor & ND & [133] \\
\hline & & methylated & 57 & $34 / 60$ & tumor & ND & [37] \\
\hline & $T S P Y$ & methylated & 100 & $\begin{array}{l}5 / 5 \text { male } \\
\text { patients }\end{array}$ & $\begin{array}{l}\text { tumor and } \\
\text { cell line }\end{array}$ & YES & [134] \\
\hline \multirow{4}{*}{$\begin{array}{l}\text { CELL FATE } \\
\text { DETERMINATION }\end{array}$} & MIB2 & methylated & 19 & $6 / 31$ & tumor & ND & [135] \\
\hline & $A P C$ & methylated & 15 & $6 / 40$ & tumor & ND & [101] \\
\hline & & methylated & 17 & $9 / 54$ & tumor & YES & [136] \\
\hline & WIF1 & methylated & NA & NA & cell line & YES & [137] \\
\hline
\end{tabular}


Table 1: Genes with an altered DNA methylation status in human CM (Continued)

\begin{tabular}{|c|c|c|c|c|c|c|c|}
\hline CHROMATIN REMODELING & NPM2 & methylated & 50 & $12 / 24$ & tumor & YES & {$[32]$} \\
\hline $\begin{array}{l}\text { DEGRADATION OF } \\
\text { MISFOLDED PROTEINS }\end{array}$ & DERL3 & methylated & 23 & $3 / 13$ & cell line & NO & [138] \\
\hline \multirow[t]{3}{*}{ DIFFERENTIATION } & ENC1 & methylated & 6 & $1 / 16$ & tumor & YES & {$[22]$} \\
\hline & GDF15 & methylated & 75 & $15 / 20$ & tumor & YES & {$[21]$} \\
\hline & HOXB13 & methylated & 20 & $4 / 20$ & tumor & YES & {$[21]$} \\
\hline \multirow[t]{7}{*}{ DNA REPAIR } & MGMT & methylated & 0 & $0 / 13$ & cell line & ND & [129] \\
\hline & & methylated & 50 & $8 / 16$ & cell line & ND & [44] \\
\hline & & methylated & 63 & $26 / 41$ & serum & NA & [130] \\
\hline & & methylated & 19 & $6 / 31$ & serum & NA & [39] \\
\hline & & methylated & 13 & $5 / 40$ & tumor & ND & [101] \\
\hline & & methylated & 31 & $26 / 84$ & tumor & ND & [139] \\
\hline & & methylated & 34 & $29 / 86$ & tumor & YES & [39] \\
\hline \multirow[t]{2}{*}{ DRUG METABOLISM } & CYP1B1 & methylated & 100 & $20 / 20$ & tumor & YES & [21] \\
\hline & DNAJC15 & methylated & 50 & $10 / 20$ & tumor & YES & [21] \\
\hline \multirow[t]{3}{*}{ EXTRACELLULAR MATRIX } & COL1A2 & methylated & 63 & $45 / 24$ & tumor & YES & [32] \\
\hline & & methylated & 80 & $16 / 20$ & tumor & YES & [21] \\
\hline & MFAP2 & methylated & 30 & $6 / 20$ & tumor & YES & [21] \\
\hline \multirow[t]{5}{*}{ IMMUNE RECOGNITION } & $B A G E$ & demethylated & 83 & $10 / 12$ & cell line & YES & [140] \\
\hline & HLA class I & methylated & NA & NA & cell line & YES & [97] \\
\hline & $H M W-M A A$ & methylated & NA & NA & $\begin{array}{l}\text { tumor and } \\
\text { cell line }\end{array}$ & YES & [93] \\
\hline & $M A G E-A 1$ & demethylated & NA & NA & cell line & YES & [45] \\
\hline & $\begin{array}{l}\text { MAGE-A2, -A3,- } \\
\text { A4 }\end{array}$ & demethylated & NA & NA & tumor & YES & [47] \\
\hline INFLAMMATION & PTGS2 & methylated & 20 & $4 / 20$ & tumor & YES & [21] \\
\hline \multirow[t]{11}{*}{ INVASION/METASTASIS } & $C C R 7$ & no CpG island & NA & NA & cell line & YES & [141] \\
\hline & $\mathrm{CDH} 1$ & methylated & 88 & $14 / 16$ & cell line & ND & [44] \\
\hline & $\mathrm{CDH} 8$ & methylated & 10 & $2 / 20$ & tumor & YES & [21] \\
\hline & $\mathrm{CDH} 13$ & methylated & 44 & $7 / 16$ & cell line & ND & [44] \\
\hline & CXCR4 & methylated & NA & NA & cell line & YES & [141] \\
\hline & DPPIV & methylated & 80 & $8 / 10$ & cell line & YES & [142] \\
\hline & $E P B 41 L 3$ & methylated & 5 & $1 / 20$ & tumor & YES & [21] \\
\hline & SERPINB5 & methylated & 100 & $7 / 7$ & cell line & ND & [143] \\
\hline & & methylated & 13 & $5 / 40$ & tumor & YES & [144] \\
\hline & LOX & methylated & 45 & $18 / 40$ & tumor & YES & [101] \\
\hline & SYK & methylated & 3 & $1 / 40$ & tumor & ND & [101] \\
\hline
\end{tabular}


Table 1: Genes with an altered DNA methylation status in human CM (Continued)

\begin{tabular}{|c|c|c|c|c|c|c|c|}
\hline & & methylated & 30 & $6 / 20$ & tumor & YES & [21] \\
\hline & TFPI-2 & methylated & 13 & $5 / 40$ & tumor & ND & [101] \\
\hline & & methylated & 29 & $5 / 17$ & tumor & YES & [145] \\
\hline & $T H B D$ & methylated & 20 & $8 / 40$ & tumor & YES & [101] \\
\hline & & methylated & 60 & $12 / 20$ & $\begin{array}{l}\text { tumor and } \\
\text { cell line }\end{array}$ & YES & [146] \\
\hline & TIMP3 & methylated & 13 & $5 / 40$ & tumor & ND & [101] \\
\hline \multirow[t]{3}{*}{ PROLIFERATION } & MT1G & methylated & 21 & $5 / 24$ & tumor & YES & [32] \\
\hline & WFDC1 & methylated & 20 & $4 / 20$ & tumor & YES & [21] \\
\hline & & methylated & 25 & $10 / 40$ & tumor & ND & [101] \\
\hline \multirow[t]{27}{*}{ SIGNALING } & DDIT4L & methylated & 29 & $7 / 24$ & tumor & YES & [32] \\
\hline & $E R a$ & methylated & 17 & $2 / 12$ & cell line & ND & [129] \\
\hline & & methylated & 50 & $8 / 16$ & cell line & ND & [44] \\
\hline & & methylated & 24 & $26 / 109$ & serum & NA & [123] \\
\hline & & methylated & 51 & $55 / 107$ & tumor & ND & [123] \\
\hline & $P G R \beta$ & methylated & 56 & $9 / 16$ & cell line & ND & [44] \\
\hline & PRDX2 & methylated & 8 & $3 / 36$ & tumor & YES & [138] \\
\hline & PTEN & methylated & 23 & $3 / 13$ & cell line & ND & [129] \\
\hline & & methylated & 62 & $23 / 37$ & serum & YES & [147] \\
\hline & & methylated & 0 & $0 / 40$ & tumor & NA & [101] \\
\hline & $3-O S T-2$ & methylated & 15 & $2 / 13$ & cell line & ND & [129] \\
\hline & & methylated & 56 & $14 / 25$ & tumor & NA & [129] \\
\hline & RARRES1 & methylated & 13 & $2 / 16$ & tumor & YES & [22] \\
\hline & $R A R \beta 2$ & methylated & 44 & $7 / 16$ & cell line & ND & [44] \\
\hline & & methylated & 46 & $6 / 13$ & cell line & YES & [129] \\
\hline & & methylated & 13 & $4 / 31$ & serum & NA & [39] \\
\hline & & methylated & 22 & $5 / 23$ & tumor & NA & [129] \\
\hline & & methylated & 20 & $5 / 25$ & tumor & YES & [129] \\
\hline & & methylated & 60 & $24 / 40$ & tumor & ND & [101] \\
\hline & & methylated & 70 & $74 / 106$ & tumor & YES & [39] \\
\hline & $R I L$ & methylated & 88 & $14 / 16$ & cell line & ND & [44] \\
\hline & SOCS1 & methylated & 75 & $30 / 40$ & tumor & ND & [101] \\
\hline & & methylated & 76 & $31 / 41$ & serum & NA & [130] \\
\hline & SOCS2 & methylated & 44 & $18 / 41$ & serum & NA & [130] \\
\hline & & methylated & 75 & $30 / 40$ & tumor & ND & [101] \\
\hline & SOCS3 & methylated & 60 & $3 / 5$ & tumor & YES & [148] \\
\hline & UNC5C & methylated & 23 & $3 / 13$ & cell line & NO & [138] \\
\hline VESCICLE TRANSPORT & Rab33A & methylated & 100 & $16 / 16$ & $\begin{array}{l}\text { tumor and } \\
\text { cell line }\end{array}$ & YES & [149] \\
\hline \multirow[t]{6}{*}{ TRANSCRIPTION } & HAND1 & methylated & 15 & $2 / 13$ & cell line & ND & [129] \\
\hline & HAND1 & methylated & 63 & $10 / 16$ & cell line & ND & [44] \\
\hline & OLIG2 & methylated & 63 & $10 / 16$ & cell line & ND & [44] \\
\hline & $N K X 2-3$ & methylated & 63 & $10 / 16$ & cell line & ND & [44] \\
\hline & PAX2 & methylated & 38 & $6 / 16$ & cell line & ND & [44] \\
\hline & PAX7 & methylated & 31 & $5 / 16$ & cell line & ND & [44] \\
\hline
\end{tabular}


Table 1: Genes with an altered DNA methylation status in human CM (Continued)

\begin{tabular}{|c|c|c|c|c|c|c|c|}
\hline & RUNX3 & methylated & 23 & $3 / 13$ & cell line & ND & [129] \\
\hline & & methylated & 29 & $5 / 17$ & cell line & ND & [150] \\
\hline & & methylated & $4-17$ & $2 / 52-5 / 30$ & tissues & NA & [150] \\
\hline TBD & BST2 & methylated & 50 & $10 / 20$ & tumor & YES & [21] \\
\hline & FAM78A & methylated & 8 & $1 / 13$ & cell line & NO & [138] \\
\hline & HS3ST2 & methylated & 56 & $14 / 25$ & tumor & ND & [129] \\
\hline & $\angle R R C 2$ & methylated & 5 & $1 / 20$ & tumor & YES & [21] \\
\hline & $L X N$ & methylated & 95 & $19 / 20$ & tumor & YES & [21] \\
\hline & PCSK1 & methylated & 60 & $12 / 20$ & tumor & YES & [21] \\
\hline & PPP1R3C & methylated & 25 & $4 / 16$ & tumor & YES & [22] \\
\hline & PTPRG & methylated & 8 & $1 / 13$ & cell line & NO & [138] \\
\hline & $Q P C T$ & methylated & 100 & $20 / 20$ & tumor & YES & [21] \\
\hline & $S L C 27 A 3$ & methylated & 46 & $6 / 13$ & cell line & NO & [138] \\
\hline
\end{tabular}

a, methylation status of the gene found in CM as compared to that found in normal tissue;

b, gene symbol: APAF-1, Apoptotic Protease Activating Factor 1; APC, adenomatous polyposis coli; BAGE, B melanoma antigen; BST2, bone marrow stromal cell antigen 2; CCR7, chemokine (C-C motif) receptor 7; CDH1, cadherin 1;CDH8, cadherin 8; CDH13, cadherin 13; CDKN1B, cyclindependent kinase inhibitor 1B; CDKN1C, cyclin-dependent kinase inhibitor 1C; CDKN2A, cyclin-dependent kinase inhibitor 2A; COL1A2, alpha 2 type I collagen; CXCR4, chemokine (C-X-C motif) receptor 4; CYP1B1, cytochrome P450, family 1, subfamily B, polypeptide 1; DAPK, deathassociated protein kinase; DDIT4L, DNA-damage-inducible transcript 4-like; DERL3, Der1-like domain family, member 3; DNAJC15, DnaJ homolog, subfamily C, member 15; DPPIV, dipeptidyl peptidase IV; ENC1, ectodermal-neural cortex-1; EPB41L3, erythrocyte membrane protein band 4.1-like 3; ERa, Estrogen Receptor alpha; FAM78A, Family with sequence similarity 78, member A; GDF15, growth differentiation factor 15; HAND1, heart and neural crest derivatives expressed 1; HLA class I, human leukocyte class I antigen; HMW-MAA, high molecular weight melanoma associated antigen; HOXB13, homeobox B13; HS3ST2, heparan sulfate (glucosamine) 3-O-sulfotransferase 2; HSPB6, heat shock protein, alpha-crystallin-related, B6; HSPB8 heat shock 22 kDa protein 8; LRRC2, leucine rich repeat containing 2; LOX, lysyl oxidase; LXN, latexin; MAGE, melanoma-associated antigen, MFAP2, microfibrillar-associated protein 2; MGMT, O-6-methylguanine-DNA methyltransferase; MIB2, mindbomb homolog 2; MT1G, metallothionein 1G; NKX2-3, NK2 transcription factor related, locus 3; NPM2, nucleophosmin/nucleoplasmin 2; OLIG2, oligodendrocyte lineage transcription factor 2; PAX2, paired box 2; PAX7, paired box 7; PCSK1, proprotein convertase subtilisin/kexin type 1 ; PGR $\beta$, progesterone receptor $\beta$; PPP1R3C, protein phosphatase 1, regulatory (inhibitor) subunit 3C; PRDX2, Peroxiredoxin; PTEN, Phosphatase and tensin homologue; PTGS2, prostaglandin-endoperoxide synthase 2; PTPRG, Protein tyrosine phosphatase, receptor type, G; QPCT, glutaminyl-peptide cyclotransferase; RARB, Retinoid Acid Receptor $\beta 2$; RASSF1A, RAS associacion domain family 1 ; RIL, Reversion-induced LIM; RUNX3, runt-related transcription factor 3; SERPINB5, serpin peptidase inhibitor, clade B, member 5; SLC27A3, Solute carrier family 27; SOCS, suppressor of cytokine signaling; SYK, spleen tyrosine kinase; TFPI-2, Tissue factor pathway inhibitor-1; THBD, thrombomodulin; TIMP3, tissue inhibitor of metalloproteinase 3; TMS1, Target Of Methylation Silencing 1; TNFRSF10C, tumor necrosis factor receptor superfamily, member 10C; TNFRSF10D, tumor necrosis factor receptor superfamily, member 10D; TP53INP1, tumor protein p53 inducible nuclear protein 1; TPM1, tropomyosin 1 (alpha); TRAILR1, TNF-related apoptosis inducing ligand receptor 1; TSPY, testis specific protein, Y-linked; UNC5C, Unc-5 homologue C; WFDC1, WAP four-disulfide core domain 1; WIF1, Wnt inhibitory factor 1; XAF1, XIAP associated factor 1.

c, NA, not applicable; ND, not done; TBD, to be determined.

stage. In particular, the TSG WIF1,TFPI2, RASSF1A, and SOCS1, and the methylated in tumors (MINT) loci 17 and 31 , showed a statistically significant higher frequency of methylation from AJCC stage I to stage IV tumors [42].

Besides TSG hypermethylation, genome-wide hypomethylation might contribute to tumorigenesis and cancer progression by promoting genomic instability, reactivating endogenous parasitic sequences and inducing the expression of oncogenes [43]. In this context, Tellez et al measured the level of methylation of the LINE- 1 and Alu repetitive sequences to estimate the genome wide methylation status of CM cell lines [44]. With this approach they were able to demonstrate that $\mathrm{CM}$ cell lines do have hypomethylated genomes as compared to melanocytes. Moreover, the extent of repetitive elements hypomethyla- tion inversely correlated with the number of TSG aberrantly inactivated by promoter hypermethylation. The data obtained are particularly interesting since they shed initial light on how the two apparently antithetical phenomena of TSG hypermethylation and global loss of genomic 5-methylcytosine content might be interconnected. In fact, it could be speculated that, upon an initial genome-wide demethylation wave, the cell attempts to re-establish methylation patterns of repetitive elements. This wave of re-methylation could find promoter CpG islands more prone to de novo methylation, thus resulting in a more frequent silencing of TSG [44]. On the other hand, a direct association was found between genomewide demethylation and de novo expression of tumor associated antigens belonging to the Cancer Testis Anti- 
gens (CTA) family (e.g., MAGE-A and NY-ESO genes) [45-47]. CTA are not expressed in normal tissues except testis and placenta, while they are expressed with variable frequencies in CM tissues [47]. This characteristic tissue distribution, and their ability to generate both cellular and humoral immune responses, identified CTA as ideal targets for immunotherapy of CM patients, and led to the development of several clinical trials that are providing promising therapeutic results [48]. Recent data demonstrated that the frequently observed intratumoral heterogeneity of CTA expression, which might impair the clinical success of CTA-based immunotherapies, is itself sustained by the intratumoral heterogeneous methylation of their promoters [49]. This promoter methylation heterogeneity is further inherited at single cell level, propagating the heterogeneous CTA expression profile to daughter generations [50]. The reported association between aberrant hypomethylation of CTA promoters and CTA expression has been most recently confirmed also on populations of putative CM stem cells [51], providing further support to the key role of deregulated DNA methylation in CM development and progression, and on the potential of CTA as therapeutic targets in CM [52].

\section{Histone post-translational modifications}

In contrast to the massive information existing on the altered DNA methylation patterns occurring in CM, the data available on aberrant post-translational modifications of histones are comparatively limited and mostly indirect, being frequently just inferred from the modulation of gene expression observed following treatment with pharmacologic inhibitors of histone-modifying enzymes (i.e., HDACi). This essential lack of direct information likely reflects the more challenging approaches that are required for evaluating histone modifications associated to the transcriptional status of specific genes. In this respect, selected issues are: i) the myriad of combinations of post-translational modifications that are possible for each histone; ii) the requirement of chromatin immunoprecipitation approaches with antibodies specific for each histone modification; and, iii) the need of huge amounts of starting DNA, which essentially precluded the evaluation of tumor tissues. These limitations, however, are likely to be overcome soon thanks to the availability of the new generation high-throughput technologies and whole genome amplification protocols.

Despite these restrictions, the available data suggest that aberrant post-translational modifications of histones, and in particular their hypoacetylation, profoundly influence CM cell biology by affecting cell cycle regulation, cell signaling, differentiation, DNA repair, apoptosis, invasion and immune response (Table 2). Among these, the alterations of cell cycle regulation and apoptosis are the better characterized, and mainly involve histone hypoacetylation-mediated down-regulation of CDKN1A/ P21, and of the pro-apoptotic proteins APAF-1, BAX, BAK, BID, BIM, caspase 3 and caspase 8 [53-56]. These findings might, to some extent, provide a molecular background for a peculiar characteristic of CM. In fact, CM cells usually express high levels of wild type p53, which represents the master regulator of DNA repair that directs cells to apoptosis in case of DNA repair failure [57]. Despite this, CM cells are extremely resistant to undergoing apoptosis following conventional cytotoxic therapies. In light of the information above, it could be speculated that this behaviour of CM cells could depend, at least in part, on the epigenetic impairment of apoptotic pathways.

Besides histone acetylation status, initial studies have addressed a possible role of aberrant histone methylation in $\mathrm{CM}$. Along this line, $\mathrm{CM}$ cells were found to express up-regulated levels of the H3K27 HMT EZH2 [58]. Even though no direct evidence has been provided, overexpression of EZH2 could help CM cells to evade senescence, by suppressing $\mathrm{p} 16^{\mathrm{INK} 4 \mathrm{~A}}$ expression, and to invade surrounding tissues, by repressing E-cadherin [59]. Moreover, a reduced expression of the histone demethylase KDM5B, which targets trimethylated $\mathrm{H} 3 \mathrm{~K} 4$, was found in advanced CM [60]. In A375 CM cells, ectopic expression of KDM5B resulted in the block of the cell cycle in G1/S, accompanied by a significant decrease of DNA replication and cellular proliferation, suggesting this histone demethylase might function as a TSG in CM [60]. These are clearly very preliminary data, which need confirmation in large series of CM tissues and the direct identification of the target genes to define the role of histone methylation in CM biology.

\section{MicroRNAs}

Up to now only limited data is available on miRNA deregulation in CM and on its potential involvement in driving $\mathrm{CM}$ tumorigenesis and progression (Table 3). Most of the information were derived from general studies on miRNA expression in tumors of different histotype, among which $\mathrm{CM}$ represented a variable proportion (reviewed in [61]). Yet, a CM-specific miRNA profiling study has been recently published, reporting extensive modifications of miRNA patterns in CM as compared to normal melanocytes, as well as identifying modifications of miRNA expression that are potentially associated to the different phases of CM pathogenetic process [62]. Accordingly, Levati et al showed that miR-17-5p, miR18a, miR-20a and miR-92a were over-expressed, while miR-146a, miR-146b, and miR155 were down-regulated in the majority of examined CM cell lines as compared to normal melanocytes. Furthermore, the ectopic expression of miR-155 in CM cells significantly inhibited prolif- 


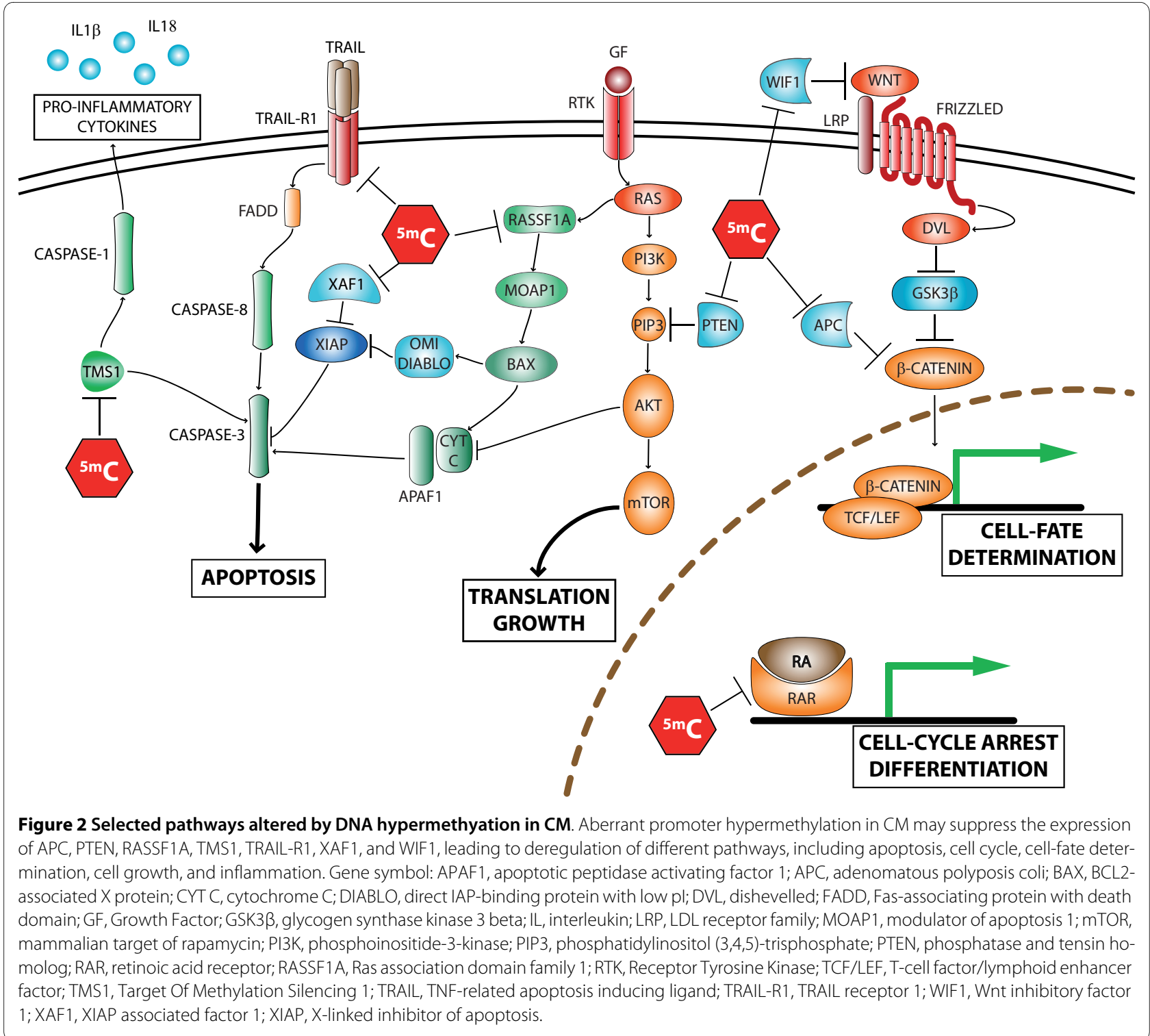

eration and induced apoptosis, though the miRNA target mRNA(s) responsible for this activity have not been identified yet [63]. These upcoming evidences, together with initial studies that have identified the target genes regulated by specific miRNA and their functional effect on tumor biology, strongly suggest that miRNA deregulation might play an important role in CM. Along this line, the transcription factor MITF, a master regulator of melanocytes biology, was found to be regulated by at least 2 different miRNAs, miR-137 and miR-182, which showed opposite alterations. MiR-137 was shown to be downregulated in selected CM cell lines through the amplification of a Variable Number of Tandem Repeats sequence in its $5^{\prime}$ untranslated region, which altered the secondary structure of pri-miR-137, preventing the production of the mature miRNA. This lack of inhibition by miR-137 resulted in the over-expression of MITF in CM cells [64]. On the other hand, miR-182 has been identified as being frequently over-expressed through gene amplification in different $\mathrm{CM}$ cell lines and tissues, where it contributed to an increased survival and metastatic potential of neoplastic cells by repressing MITF and FOXO3. Of note, miR-182 appeared to be particularly involved in CM progression, being increasingly over-expressed with evolution from primary to metastatic disease [65]. The interplay between the reported opposing alterations involving miR-137 and miR-182 might represent a molecular mechanism able to orchestrate the complex modulation of MITF expression that appears to be required during CM "lifespan", including its up-regulation in the initial phases of CM tumorigenesis and its down-regulation necessary for $\mathrm{CM}$ cells to acquire invasive and meta- 
Table 2: Genes potentially regulated by modifications of histone acetylation in human CM

\begin{tabular}{|c|c|c|c|c|c|c|}
\hline PATHWAY & GENE & SOURCE & HDACi & $\begin{array}{l}\text { MODULATION } \\
\text { BY HDACi }\end{array}$ & FUNCTION & REFERENCE \\
\hline \multirow[t]{11}{*}{ APOPTOSIS } & BAKa & cell line & $\mathrm{SBHA}^{b}$ & up-regulation & pro-apoptotic & {$[54,106,151]$} \\
\hline & $\mathrm{BAX}$ & cell line & $\mathrm{SBHA}, \mathrm{NaB}$ & up-regulation & pro-apoptotic & {$[54,56,106,151]$} \\
\hline & $\mathrm{BCL}-\mathrm{X}$ & cell line & SAHA, SBHA, TSA & down-regulation & anti-apoptotic & {$[54,106,151,152]$} \\
\hline & BID & cell line & SBHA & up-regulation & pro-apoptotic & [151] \\
\hline & BIM & cell line & SBHA & up-regulation & pro-apoptotic & {$[54,106,151]$} \\
\hline & CASP3 & cell line & SBHA & up-regulation & pro-apoptotic & [151] \\
\hline & CASP8 & cell line & SBHA & up-regulation & pro-apoptotic & [151] \\
\hline & MCL-1 & cell line & SBHA & down-regulation & anti-apoptotic & {$[54,106,151]$} \\
\hline & TRAILR1 & cell line & SAHA, TSA & up-regulation & pro-apoptotic & [152] \\
\hline & TRAILR2 & cell line & TSA, SAHA & up-regulation & pro-apoptotic & [152] \\
\hline & XIAP & cell line & SBHA & down-regulation & anti-apoptotic & {$[54,106,151]$} \\
\hline \multirow[t]{7}{*}{ CELL CYCLE } & CCNA & cell line & TSA & down-regulation & $\begin{array}{c}\text { promotes cell } \\
\text { cycle progression }\end{array}$ & [53] \\
\hline & CCND1 & cell line & TSA, VPA & down-regulation & $\begin{array}{l}\text { promotes cell } \\
\text { cycle progression }\end{array}$ & {$[53,114]$} \\
\hline & CCND3 & cell line & TSA & up-regulation & $\begin{array}{l}\text { promotes cell } \\
\text { cycle progression }\end{array}$ & [53] \\
\hline & CCNE & cell line & TSA & up-regulation & $\begin{array}{l}\text { promotes cell } \\
\text { cycle progression }\end{array}$ & {$[53,153]$} \\
\hline & CDKN1A & cell line & $\begin{array}{c}\text { LAQ824, VPA, MS- } \\
275, \mathrm{NaB}, \mathrm{TSA}\end{array}$ & up-regulation & $\begin{array}{l}\text { inhibits cell cycle } \\
\text { progression }\end{array}$ & $\begin{array}{c}{[53,110,114,154-} \\
157]\end{array}$ \\
\hline & CDKN2A & cell line & VPA & up-regulation & $\begin{array}{l}\text { inhibits cell cycle } \\
\text { progression }\end{array}$ & [114] \\
\hline & TP53 & cell line & TSA & down-regulation & $\begin{array}{l}\text { inhibits cell cycle } \\
\text { progression }\end{array}$ & [53] \\
\hline \multirow[t]{4}{*}{ DNA REPAIR } & KU70 & cell line & $\mathrm{NaB}, \mathrm{SAHA}, \mathrm{TSA}$ & down-regulation & $\begin{array}{c}\text { repairing } \\
\text { radiation-induced } \\
\text { DNA damages }\end{array}$ & {$[119,120]$} \\
\hline & KU80 & cell line & SAHA & down-regulation & $\begin{array}{c}\text { repairing } \\
\text { radiation-induced } \\
\text { DNA damages }\end{array}$ & [120] \\
\hline & KU86 & cell line & $\mathrm{NaB}, \mathrm{TSA}$ & down-regulation & $\begin{array}{c}\text { repairing } \\
\text { radiation-induced } \\
\text { DNA damages }\end{array}$ & [119] \\
\hline & RAD50 & cell line & SAHA & down-regulation & $\begin{array}{l}\text { repairing } \\
\text { radiation-induced } \\
\text { DNA damages }\end{array}$ & [120] \\
\hline \multirow[t]{4}{*}{$\begin{array}{l}\text { INVASION/ } \\
\text { METASTASIS }\end{array}$} & CCR7 & cell line & TSA & up-regulation & $\begin{array}{l}\text { promotes cell } \\
\text { migration }\end{array}$ & [141] \\
\hline & CXCR4 & cell line & TSA & up-regulation & $\begin{array}{l}\text { promotes cell } \\
\text { migration }\end{array}$ & [141] \\
\hline & MMP10 & cell line & Apicidin & down-regulation & $\begin{array}{l}\text { promotes } \\
\text { invasion }\end{array}$ & [158] \\
\hline & MMP2 & cell line & Apicidin & up-regulation & $\begin{array}{l}\text { promotes } \\
\text { invasion }\end{array}$ & [158] \\
\hline
\end{tabular}


Table 2: Genes potentially regulated by modifications of histone acetylation in human CM (Continued)

\begin{tabular}{|c|c|c|c|c|c|c|}
\hline \multirow[t]{3}{*}{$\begin{array}{l}\text { SIGNALING } \\
\end{array}$} & OSMR & cell line & TSA & up-regulation & $\begin{array}{l}\text { anti-proliferative } \\
\text { signals }\end{array}$ & [159] \\
\hline & RAP 1 & cell line & FK228 & up-regulation & $\begin{array}{l}\text { inhibits RAS } \\
\text { signaling }\end{array}$ & [160] \\
\hline & RARB & cell line & LAQ824 & up-regulation & $\begin{array}{l}\text { transduces RA } \\
\text { signals }\end{array}$ & [110] \\
\hline \multicolumn{7}{|c|}{$\begin{array}{l}\text { a, gene symbol: BAK, BCL2-antagonist/killer; Bax, BCL2-associated X protein; Bid, BH3 interacting domain death agonist; BIM, bcl-2 interacting } \\
\text { mediator of cell death; CASP3,caspase-3; CASP8, Caspase 8; CCNA, cyclin A; CCND1, cyclin D1; CCND3, cyclin D3; CCNE, cyclin E; CCNE, Cyclin } \\
\text { CDKN1A, cyclin-dependent kinase inhibitor 1A; LEF-1, lymphoid enhancer factor-1; MCL-1, myeloid cell leukemia sequence 1; MMP2, matrix } \\
\text { metallopeptidase 2; MMP10, matrix metallopeptidase 10; OSMR, oncostatin M receptor beta; TP53, tumor protein p53; TRAILR2, TNF-related } \\
\text { apoptosis inducing ligand receptor 2; XIAP, X-linked inhibitor of apoptosis. }\end{array}$} \\
\hline
\end{tabular}

static potential. Recent data have suggested that also the expression of the oncogene MET, which is involved in triggering an "invasive growth" program characterized by enhanced cell motility, invasion and resistance to apoptosis, might be regulated by miRNA in CM. Indeed, miR$34 b, m i R-34 c$, and miR-199a* were found to negatively regulate MET in cancer cell lines of different histotype, and their exogenous expression in primary CM cell cultures led to a reduced expression of MET and to an impaired MET-mediated motility [66]. Another gene that is crucial for $\mathrm{CM}$ progression is integrin $\beta 3$. Its overexpression is frequently observed in $\mathrm{CM}$ and leads to enhanced migratory and invasive potential of neoplastic cells. In this context, Muller et al have recently demonstrated that the miRNA let-7a directly regulates integrin $\beta 3$ by targeting its 3 ' untranslated region, and that the frequent loss of let-7a in CM is the major cause of integrin $\beta 3$ over-expression [67]. Another member of the let-7 family, let7-b, was shown to be down-regulated in CM. Let-7b was able to suppress, both directly and indirectly, different cell cycle promoting proteins, including cyclins A, D1, D3 and Cyclin-dependent kinase 4. Thus, it appears that Let-7b is an important negative regulator of $\mathrm{CM}$ cell growth and proliferation, and its loss likely plays a crucial role in providing neoplastic cells of the melanocytic lineage with oncogenic properties [68].

As suggested by the case of let-7b, a peculiar behaviour of miRNA deregulation is that the specific alteration of a single miRNA species may impact the biology of CM cells by concurrently affecting multiple proteins/pathways. Along with this notion, the increased expression of miR$221 / 222$, occurring during CM progression from primary to metastatic disease, was described to down-regulate both p27 and c-KIT, leading to a concomitant increase in cell proliferation and differentiation blockade of CM cells [69].

Lastly, besides mediating epigenetic regulation of gene expression, miRNA can be themselves targets of epigenetic regulation. This is the case, for instance, of miR-34a, which is silenced by aberrant $\mathrm{CpG}$ island methylation at its promoter in $43.2 \%$ of CM cell lines and $62.5 \%$ of primary CM tissues analyzed [70]. However, despite its frequent inactivation in $\mathrm{CM}$, further studies are required to define its role in CM biology.

\section{Epigenetic drugs}

Epigenetic deregulation leads to the concomitant impairment of multiple cellular pathways in CM, and the preservation of this aberrant status is dependent on the retained activity of DNMT and/or HDAC. Thus, both enzymes clearly represent the designated targets for epigenetic intervention in $\mathrm{CM}$, and different inhibitors of their activity have been so far described and utilized in the clinical setting.

\section{DNMT inhibitors (for review see [71])}

Nucleoside inhibitors are represented by different cytosine analogues that function as substrate for DNMT, including 5-azacytidine (Vidaza), 5-AZA-CdR (Dacogen), S110 [72] and zebularine. To exert their activity, nucleoside inhibitors must be incorporated into the genomic DNA of the target cell during the S-phase of the cell cycle. Their methylation by DNMT results in a stable covalent bond between the modified DNA and the enzyme, which is irreversibly inactivated and trapped into the DNA $[73,74]$. The resulting cellular depletion of DNMT activity leads to the passive demethylation of the neosynthesized DNA [73,74]. These cytidine analogs are the most potent DNA hypomethylating agents available so far, and 5-aza-cytidine and 5-AZA-CdR have been positively used in hematologic malignancies, being also able to induce in vivo the expression of specific genes (P16, several CTA) in both hemopoietic [acute myeloid leukemia (AML), myelodysplastic syndrome (MDS)] [75] and solid tumors (lung cancer, esophageal cancer, malignant pleural mesothelioma) [76]. Their use, however, is associated with a significant cytotoxicity that may be mediated, at least in part, by the triggering of additional cellular events (e.g., genotoxic stress responses), which are not related to hypomethylation but strictly inherent with the mode of action of these drugs. 
Non nucleoside inhibitors directly block the DNMT activity without needing to be incorporated into the DNA, thus are not expected to give toxicity related to the covalent trapping of the enzyme. Within this class, different compounds have been associated with different modalities of action: i) procaine and procainamide interfere with the binding of DNMT to the substrate DNA; ii) (-)-epigallocatechin-3-gallate and RG108 bind and block the DNMT catalytic site; iii) the MG98 antisense oligonucleotide triggers degradation of DNMT mRNA. Of these, MG98 has undergone clinical evaluation in Phase I and II trials conducted in patients with solid (colorectal, cervix, esophagus, lung, ovary, renal) or hematopoietic (AML, MDS) malignancies, but failed to demonstrate any significant clinical activity [77-79].

\section{HDAC inhibitors}

HDACi (for review see [80]) can be classified into different classes based on their chemical structure: short chain fatty acids (e.g., butyrate, valproic acid), hydroxamic acids [e.g., TSA, suberoylanilide hydroxamic acid (SAHA, vorinostat, ZOLINZA), suberic bishydroxamic acid (SBHA), PXD101 (Belinostat), LAQ824], cyclic tetrapeptides [e.g., trapoxin A, apicidin, depsipeptide (romidepsin)], benzamides [e.g., MS-275 (SNDX-275), CI-994]. Most of them are suggested to act by blocking the $\mathrm{Zn}^{2+}$ containing catalytic site of HDAC. HDACi cause accumulation of acetylated histones into the nucleosomes, resulting in a more accessible and transcriptionally active chromatin structure. This activity has been linked to their ability to revert aberrant epigenetic marks in human neoplasia. Histones, however, are not the only targets for HDAC, and the comprehensive effects of HDACi may result, at least in part, from mechanisms that are unrelated to direct chromatin remodelling.

\section{Clinical translation \\ Epigenetic therapies}

Treatment of CM cells with epigenetic drugs has clearly demonstrated to have pleiotropic effects sustained by the reactivation of different pathways that became aberrantly inactivated during neoplastic transformation of melanocytes [81]. From a therapeutic perspective, it would thus be tempting to combine epigenetic intervention with conventional and/or innovative therapeutic approaches that would take specific advantages from the epigenetically-restored functionality of deregulated pathways. To this end, despite different epigenetic drugs have already been used extensively in the clinic (Table 4) [82-84], and recent in vitro and in vivo evidences show that these drugs preferentially target neoplastic cells [85-88], additional pre-clinical studies are likely required to more precisely define their effects on normal cells and to predict their safety for patients. Along this line, validation of recent investigations, reporting potential molecular markers of in vitro sensitivity/resistance to epigenetic drugs [89], is required prior to their clinical application for selecting patients who will benefit most from epigenetic treatment.

A growing body of experimental evidences identifies a potent immunomodulatory activity of epigenetic drugs. In fact, 5-AZA-CdR was able to induce or to up-regulate the expression of CTA in CM cells both in vitro and in vivo, allowing their recognition by CTA-specific cytotoxic $\mathrm{T}$ lymphocytes $(\mathrm{CTL})$, and generating high titre anti-CTA antibodies in vivo [47,85,90-92]. Moreover, 5AZA-CdR was able to revert the constitutively heterogeneous intratumoral expression of CTA, allowing an homogeneous intratumoral targeting of $\mathrm{CM}$ cells by CTA-specific CTL [49]. CTA do not appear to be the sole immunotherapeutic targets modulated by hypomethylating treatment, since the High Molecular Weight-Melanoma Associated Antigen was recently reported to be reactivated by 5-AZA-CdR in CM cells [93], and the tyrosinase-related protein 2 was reactivated by the hypomethylating treatment in B16 murine CM cells [94]. Besides tumor antigens, 5-AZA-CdR has a broader immunomodulatory activity, being able to concomitantly up-regulate molecules that are essential for the presentation of immunogenic peptides to immune cells, and for the recognition and cytotoxicity of CM cells by effector T-cells: 5-AZA$\mathrm{CdR}$ up-regulated HLA class I antigens and accessory/costimulatory molecules (e.g., CD54, CD58), resulting per $s e$ in an increased recognition of CM cells by antigen-specific CTL $[90,95-97]$. The ability of 5-AZA-CdR to reestablish the expression of different molecules required by $\mathrm{CM}$ cells to undergo immune-triggered apoptosis (TRAILR1, XAF1, RASSF1A, caspase 8), represents a further important effect that may ensure an efficient immune eradication of neoplastic cells [41,98-100]. Nevertheless, this effect might not be taken as granted, since Liu et al have recently reported that demethylating agents may also up-regulate TRAIL decoy receptors that antagonize TRAIL-induced apoptosis [101]. In this epigenetic immunomodulatory scenario, $\mathrm{HDACi}$ may contribute with their demonstrated ability to up-regulate different molecules, including: FAS, the melanoma antigen gp100, molecules involved in antigen processing and presentation (MHC class I and II antigens, TAP1, TAP2, LMP2, LMP7 and Tapasin), and the co-stimulatory molecules CD40 and B7-1/2 in B16 murine CM cells [102-105]. These modulations of the antigenic profile of CM cells associated with a significant increase in direct presentation of MHC class I- and II-restricted peptides by HDACi-treated B16 cells, and to their increased apoptosis following FASL treatment [103-105]. Similarly, human $\mathrm{CM}$ cells underwent increased apoptosis upon the synergistic action of TRAIL and the HDACi SBHA [106]. The above reported immunologic modulations, which also 
Table 3: miRNAs altered in human CM

\begin{tabular}{|c|c|c|c|c|c|}
\hline PATHWAY & miRNA & TARGETED GENE & EXPRESSIONa & SOURCE & REFERENCE \\
\hline \multirow[t]{2}{*}{ APOPTOSIS } & miR-15b & & up-regulated & tumors and cell lines & [122] \\
\hline & miR-155 & $\operatorname{NIK}^{b}(?)^{c}$, SKI (?) & down-regulated & cell lines & {$[63]$} \\
\hline \multirow[t]{7}{*}{ CELL CYCLE } & miR-193b & cyclin D1 & down-regulated & tumors & [161] \\
\hline & miR $17-92$ cluster & c-MYC & up-regulated & cell lines & {$[62,63]$} \\
\hline & miR 106-363 cluster & Rbp1-like (?) & up-regulated & cell lines & {$[62]$} \\
\hline & miR-137 & MITF & down-regulated & cell lines & {$[61,64]$} \\
\hline & miR-182 & MITF, FOXO3 & up-regulated & tumors and cell lines & {$[61,65]$} \\
\hline & miR-221/-222 & c-KIT, p27 & up-regulated & cell lines & {$[61,69]$} \\
\hline & let-7b & cyclins A, D1, D3, CDK4 & down-regulated & tumors & {$[61,68]$} \\
\hline
\end{tabular}

\begin{tabular}{|c|c|c|c|c|c|}
\hline \multirow{7}{*}{$\begin{array}{l}\text { INVASION/ } \\
\text { METASTASIS }\end{array}$} & miR-373 & & up-regulated & cell lines & {$[62]$} \\
\hline & miR-137 & MITF & down-regulated & cell lines & {$[61,64]$} \\
\hline & miR-182 & MITF, FOXO3 & up-regulated & tumors and cell lines & {$[61,65]$} \\
\hline & let-7a & ITGB3 & down-regulated & cell lines & {$[61]$} \\
\hline & $\mathrm{miR}-34 \mathrm{~b}$ & MET & down-regulated & cell lines & {$[66]$} \\
\hline & $\operatorname{miR}-34 \mathrm{c}$ & MET & down-regulated & cell lines & {$[66]$} \\
\hline & miR-199a* & MET & down-regulated & cell lines & {$[66]$} \\
\hline
\end{tabular}

\begin{tabular}{|c|c|c|c|c|}
\hline \multirow[t]{15}{*}{$\mathrm{TBD}^{\mathrm{d}}$} & $m i R-17-5 p$ & up-regulated & tumors and cell lines & {$[62,63,161]$} \\
\hline & miR-146a & down-regulated & cell lines & [63] \\
\hline & miR-146b & down-regulated & cell lines & [63] \\
\hline & miR-16 & up-regulated & tumors & [161] \\
\hline & miR-21 & up-regulated & tumors & {$[161]$} \\
\hline & miR-22 & up-regulated & tumors & [161] \\
\hline & miR-106b & up-regulated & tumors & [161] \\
\hline & miR-125b & down-regulated & tumors & [161] \\
\hline & miR-200c & down-regulated & tumors & [161] \\
\hline & miR-203 & down-regulated & tumors & [161] \\
\hline & miR-204 & down-regulated & tumors & [161] \\
\hline & miR-205 & down-regulated & tumors & [161] \\
\hline & $\operatorname{miR}-211$ & down-regulated & tumors & [161] \\
\hline & miR-214 & down-regulated & tumors & [161] \\
\hline & miR-768-3p & down-regulated & tumors & [161] \\
\hline
\end{tabular}

a, level of expression of miRNAs in CM as compared to that found in normal melanocytes;

b, gene symbol: CDK4, cycline dependent kinase 4; FOXO3, forkhead box O3; ITGB3, integrin beta 3; MITF, microphthalmia-associated transcription factor; NIK, nuclear factor-inducing kinase; Rbp1-like, retinoblastoma binding protein 1 like; SKI, v-ski sarcoma viral oncogene homolog;

c, predicted target genes that have not been confirmed are indicated with question marks (?);

$d$, TBD: to be determined. 
include an increased antigen cross presentation in vivo, likely explain the observation that vaccination of mice with HDACi-treated B16 cells induced specific antitumor immunity that was able to control the growth of established B16 tumors (therapeutic vaccination) and to prevent tumor take by subsequent challenge with B16 CM cells (prophylactic vaccination) [104]. Altogether, the information above provide a strong scientific background to translate treatments combining epigenetic drugs and immunotherapies into clinical development. Along this line, Kozar et al demonstrated that IL12 immunotherapy improves the antitumor effectiveness of 5-AZA-CdR in $\mathrm{B} 16 \mathrm{CM}$ model in mice, and that this synergism requires the presence of CD4+ and CD8+ T lymphocytes [107]. Moreover, in vivo administration of HDACi has proven particularly effective in enhancing the antitumor activity of adoptively transferred antigen- or tumor-specific $\mathrm{T}$ cells in mice, through a coordinate action on both tumor and $\mathrm{T}$ cells $[105,108]$. Indeed, besides the phenotypic modulations induced on CM cells, the immunotherapeutic activity of HDACi appeared to also rely on their ability to: i) provide a proliferative advantage to adoptively transferred cells, mediated by a preferential depletion of naïve endogenous lymphocytes in the recipient mice; ii) improve the functionality of the adoptively transferred lymphocytes, which showed a higher cytotoxic potential in vivo [108]. In this context, Gollob et al have recently performed a phase I trial of 5-AZA-CdR plus high-dose IL2 in CM and renal carcinoma patients, demonstrating that the combination is well-tolerated and that 5-AZACdR may enhance the activity of IL2 [109]. In light of these promising data, additional epigenetic-based immunotherapy studies are likely to be expected in the next future (Table 4).

Keeping on in the field of biologic therapies, 5-AZA$\mathrm{CdR}$ or HDACi in association with RA demonstrated to be able to re-express RAR- $\beta 2$. Combined treatment resulted in a reduced clonogenicity and in an impaired growth of CM cells in vivo, suggesting for the potential clinical effectiveness of this therapeutic association $[39,110]$. Recent data, however, showed that the expression of PRAME may prevent the re-activation of RAR- $\beta 2$ by epigenetic drugs. This observation led to the patenting of a therapeutic strategy that foresees treatment with an inhibitor of PRAME in conjunction, or prior, to HDACi and RA therapy (Table 5, Pat. n: CA2553886). Tumor angiogenesis has become an attractive therapeutic target in different malignancies, though it is now clear that the most efficient clinical use of anti-angiogenic drugs is through combination therapies. In this respect, epigenetic drugs might represent appealing combination partners in light of the recent demonstration that 5-AZA$\mathrm{CdR}$, zebularine and TSA counteract the pro-angiogenic stimuli mediated by tumor conditioned medium, finally resulting in a reduced vessel formation in different tumor models [111].

In addition to biologic therapies, epigenetic drugs are expected to be successful also in combination with standard cancer chemo- and radio-therapeutic approaches (Table 4). In fact, re-expression/up-regulation of caspase 8 and/or of APAF-1 by 5-AZA-CdR may sensitize CM cells to apoptosis induced by adriamycin, cisplatinum, doxorubicin, and etoposide [55,100]. Furthermore, resistance of tumor cells to alkylating drugs is associated to an increased expression of MGMT, which repairs the DNA alterations induced by these drugs. Although surprising, recent reports indicate an association between MGMT re-expression in CM cells and intragenic hypermethylation around exon 3 [112,113]. Consistently, 5-AZA-CdR treatment down-regulated MGMT activity in CM cells, partly reverting their sensitivity to alkylating drugs $[112,113]$. As far as HDACi, these agents were demonstrated to be able to sensitize CM cells to apoptosis induced by cisplatinum and topoisomerase inhibitors $[114,115]$. These data led to the development of different clinical trials with HDACi alone or combined with chemo or chemoimmunotherapeutic regimens in CM (Table 4) [116-118]. Results were promising, being the combination generally well-tolerated and frequently associated with stabilization of the disease $[116,118]$. Nevertheless, Rocca et al reported that combination of valproic acid and dacarbazine plus interferon- $\alpha$ resulted in an increased toxicity and no superior clinical efficacy as compared to the standard therapy in patients with advanced CM [117]. Thus, it appears that the clinical efficacy of HDACi combinations strictly depends on the setting in which they are utilized. Besides chemotherapeutic drugs, HDACi were demonstrated to synergize also with radiation, reducing the clonogenic survival of $\mathrm{CM}$ cells. The radiosensitizing activity of HDACi seems to be related to their ability to sensitize CM cells to radiationinduced apoptosis and to impair the ability of CM cells to repair radiation-induced DNA damages (down-regulation of the repair proteins Ku70, Ku80, Ku86 and Rad50) $[119,120]$. Altogether, the above reported data strongly support the future development of combined epigenetic chemo/radiotherapies that might overcome the currently limited efficacy of conventional therapies in CM.

\section{Prognostic and predictive epigenetic markers}

The epigenetic alterations found in CM may be exploited also to define new markers for diagnosis or prediction of disease outcome and/or response to therapy. Along this line, different patents exist promoting the analysis of the methylation status of selected genes (e.g., TSPY1, CYBA, MX1, MT2A, RPL37A, HSPB1, FABP5, BAGE) as additional diagnostic tool for $\mathrm{CM}$, which might also predict the likelihood of metastatic spreading (Table 5). Upcoming literature data have provided some initial validation 
Table 4: Ongoing clinical trials with epigenetic drugs in CM patients

\begin{tabular}{|c|c|c|c|c|c|}
\hline & Molecule (commercial name) & Tumor & Phase & Combination & Identifiera \\
\hline \multirow[t]{6}{*}{ inhibitors of DNMT } & $\begin{array}{l}\text { 5-azacytidine } \\
\text { (Vidaza) }\end{array}$ & Melanoma (Skin) & 1 & $\begin{array}{l}\text { Recombinant } \\
\text { Interferon } \mathrm{a}-2 \mathrm{~b}\end{array}$ & NCT00398450 \\
\hline & & $\begin{array}{l}\text { Kidney Cancer, Melanoma } \\
\text { (Skin) }\end{array}$ & 1 & $\begin{array}{l}\text { Recombinant } \\
\text { Interferon } a-2 b\end{array}$ & NCT00217542 \\
\hline & $\begin{array}{l}\text { 5-Aza-2'-deoxycytidine (Dacogen, } \\
\text { Decitabine) }\end{array}$ & Melanoma & I, II & $\begin{array}{l}\text { Pegylated } \\
\text { Interferon } a-2 b\end{array}$ & NCT00791271 \\
\hline & & Metastatic Melanoma & $\mathrm{I}, \mathrm{II}$ & $\begin{array}{l}\text { Temozolomide, } \\
\text { Panobinostat }\end{array}$ & NCT00925132 \\
\hline & & Melanoma & I, II & $\begin{array}{l}\text { Pegylated } \\
\text { Interferon } a-2 b\end{array}$ & NCT00791271 \\
\hline & & Melanoma & $\mathrm{I}, \mathrm{II}$ & Temozolomide & NCT00715793 \\
\hline \multirow[t]{5}{*}{ inhibitors of HDAC } & $\begin{array}{l}\text { Valproic acid } \\
\text { (Depakote, Depakote ER, Depakene, } \\
\text { Depacon, Stavzor) }\end{array}$ & Melanoma & $\mathrm{I}, \mathrm{II}$ & Karenitecin & NCT00358319 \\
\hline & $\begin{array}{l}\text { FR901228 } \\
\text { (Romidepsin) }\end{array}$ & $\begin{array}{l}\text { Intraocular Melanoma, } \\
\text { Unresectable stage III or stage } \\
\text { IV Melanoma }\end{array}$ & $\|$ & & NCT00104884 \\
\hline & $\begin{array}{l}\text { MS-275 } \\
\text { (Entinostat, SNDX-275, BAY86-5274) }\end{array}$ & Melanoma & $\|$ & & NCT00185302 \\
\hline & $\begin{array}{l}\text { Suberoylanilide hydroxamic acid, } \\
\text { SAHA (Vorinostat, Zolinza) }\end{array}$ & $\begin{array}{l}\text { NSCLC, Pancreatic Cancer, } \\
\text { Melanoma, Lymphoma }\end{array}$ & 1 & $\begin{array}{l}\text { Protesome inhibitor } \\
\mathrm{NPI}-0052\end{array}$ & NCT00667082 \\
\hline & & $\begin{array}{l}\text { Intraocular Melanoma, } \\
\text { Metastatic or Unresectable } \\
\text { Melanoma }\end{array}$ & $\|$ & & NCT00121225 \\
\hline
\end{tabular}

a, identifier of the trial as retrieved from: http://www.clinicaltrials.gov.

on the potential prognostic role of epigenetic alterations in CM. By analyzing 230 primary CM, Lahtz et al demonstrated that PTEN methylation in CM tissues is an independent predictor of impaired patient survival, though its prognostic relevance was not superior to tumor thickness and ulceration [121]. On the other hand, aberrant hypermethylation of MINT31 locus was recently found to be a significant predictor of improved overall survival in stage III CM patients. Nevertheless, the small number of patients examined in this study requires further validations to draw general conclusions [42]. Besides DNA methylation markers, initial data are suggesting that also alterations in miRNAs expression might have a prognos- tic role in CM. Indeed, a recent paper described a significant association between an up-regulated expression of miRNA miR-15b in primary CM lesions and a poor recurrence-free and overall survival of patients [122]. In line with these data, different studies have investigated the methylation status of several genes in sera of CM patients, with the aim to provide reliable soluble prognostic epigenetic markers that could be easily assayable in the routine laboratory. Albeit conducted on a small number of patients, the results of these initial studies are encouraging: i) serum $E R-\alpha$ methylation in stage IV CM patients was a negative predictor of overall and progression-free survival in patients treated with biochemother- 
Table 5: Published patents on CM epigeneticsa

\begin{tabular}{lcc}
\hline \multicolumn{1}{c}{ TITLE } & PATENT NUMBER & PUBLICATION DATE \\
& & \\
& & $15 / 10 / 2009$ \\
ADMINISTRATION OF AN INHIBITOR OF HDAC AND AN HMT INHIBITOR & WO2009126537 & $09 / 07 / 2009$ \\
USE OF METHYLATION STATUS OF MINT LOCI AND TUMOR-RELATED GENES & WO2009086472 & $02 / 07 / 2009$ \\
AS A MARKER FOR MELANOMA AND BREAST CANCER & & $28 / 05 / 2009$ \\
GENE METHYLATION IN DIAGNOSIS OF MELANOMA & US2009170083 & $09 / 04 / 2009$ \\
ADMINISTRATION OF AN INHIBITOR OF HDAC & WO2009067500 \\
MARKERS FOR MELANOMA & US2009093424 & $20 / 11 / 2008$ \\
USE OF HDAC INHIBITORS FOR THE TREATMENT OF MELANOMA & CA2684114 & $09 / 10 / 2008$ \\
UTILITY OF HIGH MOLECULAR WEIGHT MELANOMA ASSOCIATED ANTIGEN & WO2008121125 \\
IN DIAGNOSIS AND TREATMENT OF CANCER & & $12 / 06 / 2008$ \\
INHIBITORS OF DNA METHYLATION IN TUMOR CELLS & US2008138329 \\
METHODS AND PRODUCTS FOR DIAGNOSING CANCER & WO2008066878 \\
UTILITY OF HIGH MOLECULAR WEIGHT MELANOMA ASSOCIATED ANTIGEN & WO2007123697 & $05 / 06 / 2008$ \\
IN DIAGNOSIS AND TREATMENT OF CANCER & & $01 / 11 / 2007$ \\
MARKERS FOR MELANOMA & EP1840227 & \\
MARKERS FOR MELANOMA & WO2006092610 \\
COMBINED USE OF PRAME INHIBITORS AND HDAC INHIBITORS & CA2553886 & $03 / 10 / 2007$ \\
USE OF BAGE (B MELANOMA ANTIGENS) LOCI AS TUMOUR MARKERS & WO2004101822 & $08 / 09 / 2006$ \\
\hline
\end{tabular}

a, as retrieved from database search on: http://ep.espacenet.com

apy (dacarbazine or temozolomide, cisplatinum, vinblastine, interferon- $\alpha 2 b$, IL2, and tamoxifen) [123]; ii) serum RASSF1A methylation inversely correlated with overall survival and biochemotherapy response in $C M$ patients [124]. Most recently, methylation of the $p 73$ gene was found to be associated to an increased sensitivity of CM cells to alkylating agents in vitro [125], suggesting it as a potential marker to be assayed in patients to predict response to therapy. Along this line, MGMT promoter methylation has been evaluated in CM patients undergoing therapy with the alkylating agent temozolomide. A trend towards a positive correlation was found between MGMT promoter methylation level $\geq 25 \%$ and the achievement of partial clinical responses to the drug, suggesting further evaluations in clinical trials [126]. The development of new diagnostic or prognostic epigenetic tools is clearly an exploding field in the translational research of $\mathrm{CM}$, and it might also take advantage of the recent identification of genes that are hypermethylated in virtually all CM lesions (e.g., QPCT, LXN) [21] (Table 5).

\section{Conclusion}

Epigenetic alterations clearly play a major role in CM biology, and epigenetics of CM is a rapidly growing field that promises appealing therapeutic and diagnostic developments. The upcoming availability of next-genera- tion sequencing technologies, at increasingly affordable costs, is expected to allow defining the complete epigenome of CM in the near future. This in-depth knowledge will provide a full understanding of the biological aspects altered by epigenetic modifications during CM tumorigenesis and progression, granting new therapeutic targets, as well as more effective prognostic and/or predictive markers to be implemented in the daily clinical management of CM patients. Concomitantly, new generation epigenetic drugs can be expected to be developed to achieve reduced systemic toxicities, higher bioavailability, and a more specific epigenetic effect. Concerning the latter aspect, it should be kept in mind that: i) the highly effective nucleoside inhibitors of DNMT may trigger a DNA hypomethylation-unrelated cytotoxic response caused by covalent trapping of DNMT into DNA; ii) HDACi induce hyperacetylation of many non-histone proteins, resulting in cellular effects that may not depend on epigenetic regulation of gene expression. One clear future direction is therefore to find more specific epigenetic remodelling agents. Along this path, the recent definition of a three-dimensional model for the catalytic site of the human DNMT1 allowed to select in silico the small molecule RG108 as a specific inhibitor of DNMT1. RG108 was then demonstrated to inhibit the activity of purified DNMT in vitro and to hypomethylate tumor 
suppressor genes in human neoplastic cell lines, yet having a negligible toxicity as compared to nucleoside analogs [127]. This encouraging result prompts further efforts in designing new drugs with specific epigenetic remodelling properties, which could represent even more suitable agents to be implemented in epigenetic therapies in $\mathrm{CM}$ patients.

\section{Competing interests}

The authors declare that they have no competing interests.

\section{Authors' contributions}

LS and MM both conceived of the manuscript, and participated in its design and coordination. All authors made intellectual contributions and participated in the acquisition, analysis and interpretation of literature data, have been involved in drafting the manuscript and approved the final manuscript.

\section{Acknowledgements}

This work was supported in part by grants from the Associazione Italiana per la Ricerca sul Cancro (grants number: IG 6038 and MFAG 9195), Progetto 3 Istituto Superiore di Sanità-Alleanza Contro il Cancro, Istituto Superiore di Sanità-Malattie Rare, Istituto Toscano Tumori, Fondazione Monte dei Paschi di Siena, and The Harry Lloyd Charitable Trust.

\section{Author Details}

${ }^{1}$ Cancer Bioimmunotherapy Unit, Centro di Riferimento Oncologico, Istituto di Ricovero e Cura a Carattere Scientifico, Via F. Gallini 2, 33081 Aviano, Italy and 2Division of Medical Oncology and Immunotherapy, Department of Oncology, University Hospital of Siena, Istituto Toscano Tumori, Strada delle Scotte 14, 53100 Siena, Italy

Received: 16 February 2010 Accepted: 11 June 2010

Published: 11 June 2010

\section{References}

1. Markovic SN, Erickson LA, Rao RD, Weenig RH, Pockaj BA, Bardia A, Vachon CM, Schild SE, McWilliams RR, Hand JL, Laman SD, Kottschade LA, Maples WJ, Pittelkow MR, Pulido JS, Cameron JD, Creagan ET: Malignant melanoma in the 21st century, part 1: epidemiology, risk factors, screening, prevention, and diagnosis. Mayo Clin Proc 2007, 82:364-380

2. Houghton AN, Polsky D: Focus on melanoma. Cancer Cell 2002, 2:275-278.

3. Balch CM, Buzaid AC, Soong SJ, Atkins MB, Cascinelli N, Coit DG, Fleming ID, Gershenwald JE, Houghton A Jr, Kirkwood JM, McMasters KM, Mihm MF, Morton DL, Reintgen DS, Ross MI, Sober A, Thompson JA, Thompson JF: Final version of the American Joint Committee on Cancer staging system for cutaneous melanoma. J Clin Oncol 2001, 19:3635-3648.

4. Cummins DL, Cummins JM, Pantle H, Silverman MA, Leonard AL, Chanmugam A: Cutaneous malignant melanoma. Mayo Clin Proc 2006, 81:500-507

5. Schwabe M, Lubbert M: Epigenetic lesions in malignant melanoma. Curr Pharm Biotechnol 2007, 8:382-387.

6. Jones PA, Baylin SB: The epigenomics of cancer. Cell 2007, 128:683-692.

7. Guil S, Esteller M: DNA methylomes, histone codes and miRNAs: tying it all together. Int J Biochem Cell Biol 2009, 41:87-95.

8. Pradhan S, Bacolla A, Wells RD, Roberts RJ: Recombinant human DNA (cytosine-5) methyltransferase. I. Expression, purification, and comparison of de novo and maintenance methylation. $\mathrm{J}$ Biol Chem 1999, 274:33002-33010.

9. Okano M, Xie S, Li E: Cloning and characterization of a family of novel mammalian DNA (cytosine-5) methyltransferases. Nat Genet 1998, 19:219-220

10. Okano M, Bell DW, Haber DA, Li E: DNA methyltransferases Dnmt3a and Dnmt3b are essential for de novo methylation and mammalian development. Cell 1999, 99:247-257.

11. Rhee I, Jair KW, Yen RW, Lengauer C, Herman JG, Kinzler KW, Vogelstein B, Baylin SB, Schuebel KE: CpG methylation is maintained in human cancer cells lacking DNMT1. Nature 2000, 404:1003-1007.
12. Rhee I, Bachman KE, Park BH, Jair KW, Yen RW, Schuebel KE, Cui H, Feinberg AP, Lengauer C, Kinzler KW, Baylin SB, Vogelstein B: DNMT1 and DNMT3b cooperate to silence genes in human cancer cells. Nature 2002, 416:552-556.

13. Kim GD, Ni J, Kelesoglu N, Roberts RJ, Pradhan S: Co-operation and communication between the human maintenance and de novo DNA (cytosine-5) methyltransferases. EMBO J 2002, 21:4183-4195.

14. Paz MF, Wei S, Cigudosa JC, Rodriguez-Perales S, Peinado MA, Huang TH Esteller M: Genetic unmasking of epigenetically silenced tumor suppressor genes in colon cancer cells deficient in DNA methyltransferases. Hum Mol Genet 2003, 12:2209-2219.

15. Klose RJ, Bird AP: Genomic DNA methylation: the mark and its mediators. Trends Biochem Sci 2006, 31:89-97.

16. Strathdee G, Brown R: Aberrant DNA methylation in cancer: potential clinical interventions. Expert Rev Mol Med 2002, 4:1-17.

17. Cheung P, Lau P: Epigenetic regulation by histone methylation and histone variants. Mol Endocrinol 2005, 19:563-573.

18. Taverna SD, Li H, Ruthenburg AJ, Allis CD, Patel DJ: How chromatinbinding modules interpret histone modifications: lessons from professional pocket pickers. Nat Struct Mol Biol 2007, 14:1025-1040.

19. Hashimshony T, Zhang J, Keshet I, Bustin M, Cedar H: The role of DNA methylation in setting up chromatin structure during development. Nat Genet 2003, 34:187-192.

20. Yoo CB, Jones PA: Epigenetic therapy of cancer: past, present and future. Nat Rev Drug Discov 2006, 5:37-50.

21. Muthusamy V, Duraisamy S, Bradbury CM, Hobbs C, Curley DP, Nelson B, Bosenberg M: Epigenetic silencing of novel tumor suppressors in malignant melanoma. Cancer Res 2006, 66:11187-11193.

22. Bonazzi VF, Irwin D, Hayward NK: Identification of candidate tumor suppressor genes inactivated by promoter methylation in melanoma. Genes Chromosomes Cancer 2009, 48:10-21.

23. Hoek KS: DNA microarray analyses of melanoma gene expression: a decade in the mines. Pigment Cell Res 2007, 20:466-484.

24. Wang RY, Gehrke CW, Ehrlich M: Comparison of bisulfite modification of 5-methyldeoxycytidine and deoxycytidine residues. Nucleic Acids Res 1980, 8:4777-4790.

25. Frommer M, McDonald LE, Millar DS, Collis CM, Watt F, Grigg GW, Molloy $\mathrm{PL}$, Paul CL: A genomic sequencing protocol that yields a positive display of 5-methylcytosine residues in individual DNA strands. Proc Natl Acad Sci USA 1992, 89:1827-1831.

26. Colella S, Shen L, Baggerly KA, Issa JP, Krahe R: Sensitive and quantitative universal Pyrosequencing methylation analysis of $\mathrm{CpG}$ sites. Biotechniques 2003, 35:146-150.

27. Brena RM, Auer H, Kornacker K, Hackanson B, Raval A, Byrd JC, Plass C: Accurate quantification of DNA methylation using combined bisulfite restriction analysis coupled with the Agilent 2100 Bioanalyzer platform. Nucleic Acids Res 2006, 34:e17.

28. Herman JG, Graff JR, Myohanen S, Nelkin BD, Baylin SB: Methylationspecific PCR: a novel PCR assay for methylation status of $\mathrm{CpG}$ islands. Proc Natl Acad Sci USA 1996, 93:9821-9826.

29. Eads CA, Danenberg KD, Kawakami K, Saltz LB, Blake C, Shibata D, Danenberg PV, Laird PW: MethyLight: a high-throughput assay to measure DNA methylation. Nucleic Acids Res 2000, 28:E32

30. Yang AS, Estecio MR, Doshi K, Kondo Y, Tajara EH, Issa JP: A simple method for estimating global DNA methylation using bisulfite PCR of repetitive DNA elements. Nucleic Acids Res 2004, 32:e38.

31. Stach D, Schmitz OJ, Stilgenbauer S, Benner A, Dohner H, Wiessler M, Lyko F: Capillary electrophoretic analysis of genomic DNA methylation levels. Nucleic Acids Res 2003, 31:E2.

32. Koga Y, Pelizzola M, Cheng E, Krauthammer M, Sznol M, Ariyan S, Narayan D, Molinaro AM, Halaban R, Weissman SM: Genome-wide screen of promoter methylation identifies novel markers in melanoma. Genome Res 2009, 19:1462-1470.

33. Ansorge WJ: Next-generation DNA sequencing techniques. $N$ Biotechnol 2009, 25:195-203.

34. Esteller M: Cancer epigenomics: DNA methylomes and histonemodification maps. Nat Rev Genet 2007, 8:286-298.

35. Dasgupta P, Chellappan SP: Chromatin immunoprecipitation assays: molecular analysis of chromatin modification and gene regulation. Methods Mol Biol 2007, 383:135-152.

36. Gonzalgo ML, Bender CM, You EH, Glendening JM, Flores JF, Walker GJ, Hayward NK, Jones PA, Fountain JW: Low frequency of p16/CDKN2A 
methylation in sporadic melanoma: comparative approaches for methylation analysis of primary tumors. Cancer Res 1997, 57:5336-5347.

37. Freedberg DE, Rigas SH, Russak J, Gai W, Kaplow M, Osman I, Turner F, Randerson-Moor JA, Houghton A, Busam K, Timothy BD, Bastian BC, Newton-Bishop JA, Polsky D: Frequent p16-independent inactivation of p14ARF in human melanoma. J Natl Cancer Inst 2008, 100:784-795.

38. Palmieri G, Capone M, Ascierto ML, Gentilcore G, Stroncek DF, Casula M, Sini MC, Palla M, Mozzillo N, Ascierto PA: Main roads to melanoma. J Transl Med 2009, 7:86.

39. Hoon DS, Spugnardi M, Kuo C, Huang SK, Morton DL, Taback B: Profiling epigenetic inactivation of tumor suppressor genes in tumors and plasma from cutaneous melanoma patients. Oncogene 2004, 23:4014-4022

40. Spugnardi M, Tommasi S, Dammann R, Pfeifer GP, Hoon DS: Epigenetic inactivation of RAS association domain family protein 1 (RASSF1A) in malignant cutaneous melanoma. Cancer Res 2003, 63:1639-1643.

41. Reu FJ, Leaman DW, Maitra RR, Bae SI, Cherkassky L, Fox MW, Rempinski DR, Beaulieu N, MacLeod AR, Borden EC: Expression of RASSF1A, an epigenetically silenced tumor suppressor, overcomes resistance to apoptosis induction by interferons. Cancer Res 2006, 66:2785-2793.

42. Tanemura A, Terando AM, Sim MS, van Hoesel AQ, de Maat MF, Morton $\mathrm{DL}$, Hoon DS: $\mathrm{CpG}$ island methylator phenotype predicts progression of malignant melanoma. Clin Cancer Res 2009, 15:1801-1807.

43. Esteller M: Epigenetics in cancer. N Engl J Med 2008, 358:1 148-1159.

44. Tellez CS, Shen L, Estecio MR, Jelinek J, Gershenwald JE, Issa JP: CpG island methylation profiling in human melanoma cell lines. Melanoma Res 2009, 19:146-155.

45. De Smet C, De Backer O, Faraoni I, Lurquin C, Brasseur F, Boon T: The activation of human gene MAGE-1 in tumor cells is correlated with genome-wide demethylation. Proc Natl Acad Sci USA 1996, 93:7149-7153.

46. De Smet C, Lurquin C, Lethe B, Martelange $V$, Boon T: DNA methylation is the primary silencing mechanism for a set of germ line- and tumorspecific genes with a CpG-rich promoter. Mol Cell Biol 1999, 19:7327-7335

47. Sigalotti L, Coral S, Nardi G, Spessotto A, Cortini E, Cattarossi I, Colizzi F, Altomonte M, Maio M: Promoter methylation controls the expression of MAGE2, 3 and 4 genes in human cutaneous melanoma. JImmunother (1997) 2002, 25:16-26.

48. Caballero OL, Chen YT: Cancer/testis (CT) antigens: potential targets for immunotherapy. Cancer Sci 2009, 100:2014-2021.

49. Sigalotti L, Fratta E, Coral S, Tanzarella S, Danielli R, Colizzi F, Fonsatti E, Traversari C, Altomonte M, Maio M: Intratumor heterogeneity of cancer/ testis antigens expression in human cutaneous melanoma is methylation-regulated and functionally reverted by 5 -aza-2'deoxycytidine. Cancer Res 2004, 64:9167-9171.

50. Fratta E, Sigalotti L, Colizzi F, Covre A, Nicolay HJ, Danielli R, Fonsatti E, Altomonte M, Calabro L, Coral S, Maio M: Epigenetically regulated clonal heritability of CTA expression profiles in human melanoma. J Cell Physiol 2010, 223:352-358.

51. Sigalotti L, Covre A, Zabierowski S, Himes B, Colizzi F, Natali PG, Herlyn M, Maio M: Cancer testis antigens in human melanoma stem cells: expression, distribution, and methylation status. J Cell Physiol 2008, 215:287-291

52. Sigalotti L, Covre A, Nicolay HJ, Coral S, Maio M: Cancer testis antigens and melanoma stem cells: new promises for therapeutic intervention. Cancer Immunol Immunother 2010, 59:487-488.

53. Florenes VA, Skrede M, Jorgensen K, Nesland JM: Deacetylase inhibition in malignant melanomas: impact on cell cycle regulation and survival. Melanoma Res 2004, 14:173-181.

54. Zhang XD, Gillespie SK, Borrow JM, Hersey P: The histone deacetylase inhibitor suberic bishydroxamate regulates the expression of multiple apoptotic mediators and induces mitochondria-dependent apoptosis of melanoma cells. Mol Cancer Ther 2004, 3:425-435.

55. Soengas MS, Capodieci P, Polsky D, Mora J, Esteller M, Opitz-Araya X, McCombie R, Herman JG, Gerald WL, Lazebnik YA, Cordon-Cardo C, Lowe SW: Inactivation of the apoptosis effector Apaf-1 in malignant melanoma. Nature 2001, 409:207-211.

56. Bandyopadhyay D, Mishra A, Medrano EE: Overexpression of histone deacetylase 1 confers resistance to sodium butyrate-mediated apoptosis in melanoma cells through a p53-mediated pathway. Cancer Res 2004, 64:7706-7710.
57. Box NF, Terzian $\mathrm{T}$ : The role of $\mathrm{p} 53$ in pigmentation, tanning and melanoma. Pigment Cell Melanoma Res 2008, 21:525-533.

58. McHugh JB, Fullen DR, Ma L, Kleer CG, Su LD: Expression of polycomb group protein EZH2 in nevi and melanoma. J Cutan Pathol 2007, 34:597-600.

59. Richards HW, Medrano EE: Epigenetic marks in melanoma. Pigment Cell Melanoma Res 2009, 22:14-29.

60. Roesch A, Becker B, Schneider-Brachert W, Hagen I, Landthaler M, Vogt T: Re-expression of the retinoblastoma-binding protein 2-homolog 1 reveals tumor-suppressive functions in highly metastatic melanoma cells. J Invest Dermatol 2006, 126:1850-1859.

61. Mueller DW, Bosserhoff AK: Role of miRNAs in the progression of malignant melanoma. Br J Cancer 2009, 101:551-556.

62. Mueller DW, Rehli M, Bosserhoff AK: miRNA expression profiling in melanocytes and melanoma cell lines reveals miRNAs associated with formation and progression of malignant melanoma. J Invest Dermatol 2009, 129:1740-1751.

63. Levati L, Alvino E, Pagani E, Arcelli D, Caporaso P, Bondanza S, Di LG, Ferracin M, Volinia S, Bonmassar E, Croce CM, D'Atri S: Altered expression of selected microRNAs in melanoma: antiproliferative and proapoptotic activity of miRNA-155. Int J Oncol 2009, 35:393-400.

64. Bemis LT, Chen R, Amato CM, Classen EH, Robinson SE, Coffey DG, Erickson PF, Shellman YG, Robinson WA: MicroRNA-137 targets microphthalmiaassociated transcription factor in melanoma cell lines. Cancer Res 2008, 68:1362-1368

65. Segura MF, Hanniford D, Menendez S, Reavie L, Zou X, varez-Diaz S, Zakrzewski J, Blochin E, Rose A, Bogunovic D, Polsky D, Wei J, Lee P, Belitskaya-Levy I, Bhardwaj N, Osman I, Hernando E: Aberrant miR-182 expression promotes melanoma metastasis by repressing $\mathrm{FOXO} 3$ and microphthalmia-associated transcription factor. Proc Natl Acad Sci USA 2009, 106:1814-1819.

66. Migliore C, Petrelli A, Ghiso E, Corso S, Capparuccia L, Eramo A, Comoglio PM, Giordano S: MicroRNAs impair MET-mediated invasive growth. Cancer Res 2008, 68:10128-10136.

67. Muller DW, Bosserhoff AK: Integrin beta 3 expression is regulated by let7a miRNA in malignant melanoma. Oncogene 2008, 27:6698-6706.

68. Schultz J, Lorenz P, Gross G, Ibrahim S, Kunz M: MicroRNA let-7b targets important cell cycle molecules in malignant melanoma cells and interferes with anchorage-independent growth. Cell Res 2008 18:549-557.

69. Felicetti F, Errico MC, Bottero L, Segnalini P, Stoppacciaro A, Biffoni M, Felli N, Mattia G, Petrini M, Colombo MP, Peschle C, Care A: The promyelocytic leukemia zinc finger-microRNA-221/-222 pathway controls melanoma progression through multiple oncogenic mechanisms. Cancer Res 2008, 68:2745-2754

70. Lodygin D, Tarasov V, Epanchintsev A, Berking C, Knyazeva T, Korner $H_{\text {, }}$ Knyazev P, Diebold J, Hermeking H: Inactivation of miR-34a by aberrant CpG methylation in multiple types of cancer. Cell Cycle 2008, 7:2591-2600.

71. Lyko F, Brown R: DNA methyltransferase inhibitors and the development of epigenetic cancer therapies. J Nat/ Cancer Inst 2005, 97:1498-1506

72. Yoo CB, Jeong S, Egger G, Liang G, Phiasivongsa P, Tang C, Redkar S, Jones PA: Delivery of 5-aza-2'-deoxycytidine to cells using oligodeoxynucleotides. Cancer Res 2007, 67:6400-6408.

73. Santi DV, Norment A, Garrett CE: Covalent bond formation between a DNA-cytosine methyltransferase and DNA containing 5-azacytosine. Proc Natl Acad Sci USA 1984, 81:6993-6997.

74. Schermelleh L, Spada F, Easwaran HP, Zolghadr K, Margot JB, Cardoso MC, Leonhardt $\mathrm{H}$ : Trapped in action: direct visualization of DNA methyltransferase activity in living cells. Nat Methods 2005, 2:751-756.

75. Sigalotti L, Altomonte M, Colizzi F, Degan M, Rupolo M, Zagonel V, Pinto A, Gattei V, Maio M: 5-Aza-2'-deoxycytidine (decitabine) treatment of hematopoietic malignancies: a multimechanism therapeutic approach? Blood 2003, 101:4644-4646

76. Schrump DS, Fischette MR, Nguyen DM, Zhao M, Li X, Kunst TF, Hancox A, Hong JA, Chen GA, Pishchik V, Figg WD, Murgo AJ, Steinberg SM: Phase I study of decitabine-mediated gene expression in patients with cancers involving the lungs, esophagus, or pleura. Clin Cancer Res 2006 , 12:5777-5785

77. Klisovic RB, Stock W, Cataland S, Klisovic MI, Liu S, Blum W, Green M, Odenike O, Godley L, Burgt JV, Van LE, Cullen M, MacLeod AR, Besterman 
JM, Reid GK, Byrd JC, Marcucci G: A phase I biological study of MG98, an oligodeoxynucleotide antisense to DNA methyltransferase 1 , in patients with high-risk myelodysplasia and acute myeloid leukemia. Clin Cancer Res 2008, 14:2444-2449.

78. Winquist E, Knox J, Ayoub JP, Wood L, Wainman N, Reid GK, Pearce L, Shah A, Eisenhauer E: Phase II trial of DNA methyltransferase 1 inhibition with the antisense oligonucleotide MG98 in patients with metastatic renal carcinoma: a National Cancer Institute of Canada Clinical Trials Group investigational new drug study. Invest New Drugs 2006, 24:159-167.

79. Davis AJ, Gelmon KA, Siu LL, Moore MJ, Britten CD, Mistry N, Klamut H, D'Aloisio S, MacLean M, Wainman N, Ayers D, Firby P, Besterman JM, Reid GK, Eisenhauer EA: Phase I and pharmacologic study of the human DNA methyltransferase antisense oligodeoxynucleotide MG98 given as a 21-day continuous infusion every 4 weeks. Invest New Drugs 2003, 21:85-97.

80. Bolden JE, Peart MJ, Johnstone RW: Anticancer activities of histone deacetylase inhibitors. Nat Rev Drug Discov 2006, 5:769-784.

81. Sigalotti L, Fratta E, Coral S, Cortini E, Covre A, Nicolay HJ, Anzalone L, Pezzani L, Di Giacomo AM, Fonsatti E, Colizzi F, Altomonte M, Calabro L, Maio M: Epigenetic drugs as pleiotropic agents in cancer treatment: biomolecular aspects and clinical applications. J Cell Physiol 2007, 212:330-344

82. Lane AA, Chabner BA: Histone deacetylase inhibitors in cancer therapy. J Clin Oncol 2009, 27:5459-5468.

83. Graham JS, Kaye SB, Brown R: The promises and pitfalls of epigenetic therapies in solid tumours. Eur J Cancer 2009, 45:1129-1136.

84. Garcia-Manero G: Demethylating agents in myeloid malignancies. Curr Opin Oncol 2008, 20:705-710.

85. Coral S, Sigalotti L, Colizzi F, Spessotto A, Nardi G, Cortini E, Pezzani L, Fratta E, Fonsatti E, Di Giacomo AM, Nicotra MR, Natali PG, Altomonte M, Maio M: Phenotypic and functional changes of human melanoma xenografts induced by DNA hypomethylation: immunotherapeutic implications. J Cell Physiol 2006, 207:58-66.

86. Weiser TS, Guo ZS, Ohnmacht GA, Parkhurst ML, Tong-On P, Marincola FM, Fischette MR, Yu X, Chen GA, Hong JA, Stewart JH, Nguyen DM, Rosenberg SA, Schrump DS: Sequential 5-Aza-2 deoxycytidinedepsipeptide FR901228 treatment induces apoptosis preferentially in cancer cells and facilitates their recognition by cytolytic T lymphocytes specific for NY-ESO-1. J Immunother (1997) 2001, 24:151-161.

87. Guo ZS, Hong JA, Irvine KR, Chen GA, Spiess PJ, Liu Y, Zeng G, Wunderlich JR, Nguyen DM, Restifo NP, Schrump DS: De novo induction of a cancer/ testis antigen by 5-aza-2'-deoxycytidine augments adoptive immunotherapy in a murine tumor model. Cancer Res 2006, 66:1105-1113

88. Schmelz K, Sattler N, Wagner M, Lubbert M, Dorken B, Tamm I: Induction of gene expression by 5-Aza-2'-deoxycytidine in acute myeloid leukemia (AML) and myelodysplastic syndrome (MDS) but not epithelial cells by DNA-methylation-dependent and -independent mechanisms. Leukemia 2005, 19:103-111.

89. Halaban R, Krauthammer M, Pelizzola M, Cheng E, Kovacs D, Sznol M, Ariyan S, Narayan D, Bacchiocchi A, Molinaro A, Kluger Y, Deng M, Tran N, Zhang W, Picardo M, Enghild JJ: Integrative analysis of epigenetic modulation in melanoma cell response to decitabine: clinical implications. PLoS One 2009, 4:e4563.

90. Coral S, Sigalotti L, Gasparollo A, Cattarossi I, Visintin A, Cattelan A, Altomonte M, Maio M: Prolonged upregulation of the expression of HLA class I antigens and costimulatory molecules on melanoma cells treated with 5-aza-2'-deoxycytidine (5-AZA-CdR). J Immunother 1999, 22:16-24.

91. dos Santos NR, Torensma R, de Vries TJ, Schreurs MW, de Bruijn DR, KaterBaats E, Ruiter DJ, Adema GJ, Van Muijen GN, van Kessel AG: Heterogeneous expression of the SSX cancer/testis antigens in human melanoma lesions and cell lines. Cancer Res 2000, 60:1654-1662.

92. Weber J, Salgaller M, Samid D, Johnson B, Herlyn M, Lassam N, Treisman J, Rosenberg SA: Expression of the MAGE-1 tumor antigen is upregulated by the demethylating agent 5-aza-2'-deoxycytidine. Cancer Res 1994, 54:1766-1771.

93. Luo W, Wang X, Kageshita T, Wakasugi S, Karpf AR, Ferrone S: Regulation of high molecular weight-melanoma associated antigen (HMW-MAA) gene expression by promoter DNA methylation in human melanoma cells. Oncogene 2006, 25:2873-2884.
94. Sanchez-Perez L, Kottke T, Diaz RM, Ahmed A, Thompson J, Chong H, Melcher A, Holmen S, Daniels G, Vile RG: Potent selection of antigen loss variants of B16 melanoma following inflammatory killing of melanocytes in vivo. Cancer Res 2005, 65:2009-2017.

95. Fonsatti E, Sigalotti L, Coral S, Colizzi F, Altomonte M, Maio M: Methylation-regulated expression of HLA class I antigens in melanoma. Int J Cancer 2003, 105:430-431.

96. Fonsatti E, Nicolay HJ, Sigalotti L, Calabro L, Pezzani L, Colizzi F, Altomonte M, Guidoboni M, Marincola FM, Maio M: Functional up-regulation of human leukocyte antigen class I antigens expression by 5-aza-2'deoxycytidine in cutaneous melanoma: immunotherapeutic implications. Clin Cancer Res 2007, 13:3333-3338.

97. Serrano A, Tanzarella S, Lionello I, Mendez R, Traversari C, Ruiz-Cabello F, Garrido F: Rexpression of HLA class I antigens and restoration of antigen-specific CTL response in melanoma cells following 5-aza-2'deoxycytidine treatment. Int J Cancer 2001, 94:243-251.

98. Bae SI, Cheriyath V, Jacobs BS, Reu FJ, Borden EC: Reversal of methylation silencing of Apo2L/TRAIL receptor 1 (DR4) expression overcomes resistance of SK-MEL-3 and SK-MEL-28 melanoma cells to interferons (IFNs) or Apo2L/TRAIL. Oncogene 2008, 27:490-498.

99. Reu FJ, Bae SI, Cherkassky L, Leaman DW, Lindner D, Beaulieu N, MacLeod $A R$, Borden EC: Overcoming resistance to interferon-induced apoptosis of renal carcinoma and melanoma cells by DNA demethylation. $J$ Clin Oncol 2006, 24:3771-3779.

100. Fulda S, Kufer MU, Meyer E, van VF, Dockhorn-Dworniczak B, Debatin KM: Sensitization for death receptor- or drug-induced apoptosis by reexpression of caspase-8 through demethylation or gene transfer. Oncogene 2001, 20:5865-5877.

101. Liu S, Ren S, Howell P, Fodstad O, Riker Al: Identification of novel epigenetically modified genes in human melanoma via promoter methylation gene profiling. Pigment Cell Melanoma Res 2008, 21:545-558.

102. Khan AN, Magner WJ, Tomasi TB: An epigenetically altered tumor cell vaccine. Cancer Immunol Immunother 2004, 53:748-754.

103. Khan AN, Gregorie CJ, Tomasi TB: Histone deacetylase inhibitors induce TAP, LMP, Tapasin genes and MHC class I antigen presentation by melanoma cells. Cancer Immunol Immunother 2008, 57:647-654.

104. Khan AN, Magner WJ, Tomasi TB: An epigenetic vaccine model active in the prevention and treatment of melanoma. J Trans/Med 2007, 5:64.

105. Murakami T, Sato A, Chun NA, Hara M, Naito Y, Kobayashi Y, Kano Y, Ohtsuki M, Furukawa Y, Kobayashi E: Transcriptional Modulation Using HDACi Depsipeptide Promotes Immune Cell-Mediated Tumor Destruction of Murine B16 Melanoma. J Invest Dermato/ 2008, 128:1506-1516.

106. Gillespie S, Borrow J, Zhang XD, Hersey P: Bim plays a crucial role in synergistic induction of apoptosis by the histone deacetylase inhibitor SBHA and TRAIL in melanoma cells. Apoptosis 2006, 11:2251-2265.

107. Kozar K, Kaminski R, Switaj T, Oldak T, Machaj E, Wysocki PJ, Mackiewicz A, Lasek W, Jakobisiak M, Golab J: Interleukin 12-based immunotherapy improves the antitumor effectiveness of a low-dose 5-Aza-2'deoxycitidine treatment in L1210 leukemia and B16F10 melanoma models in mice. Clin Cancer Res 2003, 9:3124-3133.

108. Vo DD, Prins RM, Begley JL, Donahue TR, Morris LF, Bruhn KW, de la RP, Yang MY, Mok S, Garban HJ, Craft N, Economou JS, Marincola FM, Wang E, Ribas A: Enhanced antitumor activity induced by adoptive T-cell transfer and adjunctive use of the histone deacetylase inhibitor LAQ824. Cancer Res 2009, 69:8693-8699.

109. Gollob JA, Sciambi CJ, Peterson BL, Richmond T, Thoreson M, Moran K Dressman HK, Jelinek J, Issa JP: Phase I trial of sequential low-dose 5-aza2'-deoxycytidine plus high-dose intravenous bolus interleukin-2 in patients with melanoma or renal cell carcinoma. Clin Cancer Res 2006, 12:4619-4627.

110. Kato Y, Salumbides BC, Wang XF, Qian DZ, Williams S, Wei Y, Sanni TB, Atadja P, Pili R: Antitumor effect of the histone deacetylase inhibitor LAQ824 in combination with 13-cis-retinoic acid in human malignant melanoma. Mol Cancer Ther 2007, 6:70-81.

111. Hellebrekers DM, Jair KW, Vire E, Eguchi S, Hoebers NT, Fraga MF, Esteller M, Fuks F, Baylin SB, van EM, Griffioen AW: Angiostatic activity of DNA methyltransferase inhibitors. Mol Cancer Ther 2006, 5:467-475.

112. Alvino E, Castiglia D, Caporali S, Pepponi R, Caporaso P, Lacal PM, Marra G, Fischer F, Zambruno G, Bonmassar E, Jiricny J, D'Atri S: A single cycle of treatment with temozolomide, alone or combined with O(6)- 
benzylguanine, induces strong chemoresistance in melanoma cell clones in vitro: role of O(6)-methylguanine-DNA methyltransferase and the mismatch repair system. Int J Oncol 2006, 29:785-797.

113. Christmann M, Pick M, Lage H, Schadendorf D, Kaina B: Acquired resistance of melanoma cells to the antineoplastic agent fotemustine is caused by reactivation of the DNA repair gene MGMT. Int J Cancer 2001, 92:123-129.

114. Valentini A, Gravina P, Federici G, Bernardini S: Valproic acid induces apoptosis, p16INK4A upregulation and sensitization to chemotherapy in human melanoma cells. Cancer Biol Ther 2007, 6:185-191.

115. Daud Al, Dawson J, DeConti RC, Bicaku E, Marchion D, Bastien S, Hausheer FA III, Lush R, Neuger A, Sullivan DM, Munster PN: Potentiation of a topoisomerase I inhibitor, karenitecin, by the histone deacetylase inhibitor valproic acid in melanoma: translational and phase I/II clinical trial. Clin Cancer Res 2009, 15:2479-2487.

116. Munster PN, Marchion D, Thomas S, Egorin M, Minton S, Springett G, Lee $J H$, Simon G, Chiappori A, Sullivan D, Daud A: Phase I trial of vorinostat and doxorubicin in solid tumours: histone deacetylase 2 expression as a predictive marker. Br J Cancer 2009, 101:1044-1050.

117. Rocca A, Minucci S, Tosti G, Croci D, Contegno F, Ballarini M, Nole F, Munzone E, Salmaggi A, Goldhirsch A, Pelicci PG, Testori A: A phase I-II study of the histone deacetylase inhibitor valproic acid plus chemoimmunotherapy in patients with advanced melanoma. $\mathrm{Br} J$ Cancer 2009, 100:28-36.

118. Hauschild A, Trefzer U, Garbe C, Kaehler KC, Ugurel S, Kiecker F, Eigentler T, Krissel H, Schott A, Schadendorf D: Multicenter phase II trial of the histone deacetylase inhibitor pyridylmethyl- $\mathrm{N}-\{4-[(2$-aminophenyl)carbamoyl]-benzyl\}-carbamate in pretreated metastatic melanoma. Melanoma Res 2008, 18:274-278.

119. Munshi A, Kurland JF, Nishikawa T, Tanaka T, Hobbs ML, Tucker SL, Ismail S, Stevens C, Meyn RE: Histone deacetylase inhibitors radiosensitize human melanoma cells by suppressing DNA repair activity. Clin Cancer Res 2005, 11:4912-4922.

120. Munshi A, Tanaka T, Hobbs ML, Tucker SL, Richon VM, Meyn RE: Vorinostat, a histone deacetylase inhibitor, enhances the response of human tumor cells to ionizing radiation through prolongation of gamma-H2AX foci. Mol Cancer Ther 2006, 5:1967-1974.

121. Lahtz C, Stranzenbach R, Fiedler E, Helmbold P, Dammann RH: Methylation of PTEN as a Prognostic Factor in Malignant Melanoma of the Skin. J Invest Dermatol 2009, 130:620-622.

122. Satzger I, Mattern A, Kuettler U, Weinspach D, Voelker B, Kapp A, Gutzmer R: MicroRNA-15b represents an independent prognostic parameter and is correlated with tumor cell proliferation and apoptosis in malignant melanoma. Int J Cancer 2009, 126:2553-2562.

123. Mori T, Martinez SR, O'Day SJ, Morton DL, Umetani N, Kitago M, Tanemura A, Nguyen SL, Tran AN, Wang HJ, Hoon DS: Estrogen receptor-alpha methylation predicts melanoma progression. Cancer Res 2006, 66:6692-6698

124. Mori T, O'Day SJ, Umetani N, Martinez SR, Kitago M, Koyanagi K, Kuo C, Takeshima TL, Milford R, Wang HJ, Vu VD, Nguyen SL, Hoon DS: Predictive utility of circulating methylated DNA in serum of melanoma patients receiving biochemotherapy. J Clin Oncol 2005, 23:9351-9358.

125. Shen L, Kondo Y, Ahmed S, Boumber Y, Konishi K, Guo Y, Chen X, Vilaythong JN, Issa JP: Drug sensitivity prediction by $\mathrm{CpG}$ island methylation profile in the $\mathrm{NCl}-60$ cancer cell line panel. Cancer Res 2007, 67:11335-11343.

126. Rietschel P, Wolchok JD, Krown S, Gerst S, Jungbluth AA, Busam K, Smith K, Orlow I, Panageas K, Chapman PB: Phase II study of extended-dose temozolomide in patients with melanoma. J Clin Oncol 2008, 26:2299-2304

127. Brueckner B, Boy RG, Siedlecki P, Musch T, Kliem HC, Zielenkiewicz P, Suhai $S$, Wiessler M, Lyko F: Epigenetic reactivation of tumor suppressor genes by a novel small-molecule inhibitor of human DNA methyltransferases. Cancer Res 2005, 65:6305-6311

128. Sharma BK, Smith CC, Laing JM, Rucker DA, Burnett JW, Aurelian L: Aberrant DNA methylation silences the novel heat shock protein $\mathrm{H} 11$ in melanoma but not benign melanocytic lesions. Dermatology 2006, 213:192-199.

129. Furuta J, Umebayashi Y, Miyamoto K, Kikuchi K, Otsuka F, Sugimura T, Ushijima T: Promoter methylation profiling of 30 genes in human malignant melanoma. Cancer Sci 2004, 95:962-968.
130. Marini A, Mirmohammadsadegh A, Nambiar S, Gustrau A, Ruzicka T, Hengge UR: Epigenetic inactivation of tumor suppressor genes in serum of patients with cutaneous melanoma. J Invest Dermato/ 2006, $126: 422-431$

131. Guan X, Sagara J, Yokoyama T, Koganehira Y, Oguchi M, Saida T, Taniguchi S: ASC/TMS1, a caspase- 1 activating adaptor, is downregulated by aberrant methylation in human melanoma. Int J Cancer 2003, 107:202-208.

132. Worm J, Bartkova J, Kirkin AF, Straten P, Zeuthen J, Bartek J, Guldberg P: Aberrant p27Kip1 promoter methylation in malignant melanoma. Oncogene 2000, 19:5111-5115

133. Straume O, Smeds J, Kumar R, Hemminki K, Akslen LA: Significant impact of promoter hypermethylation and the $540 \mathrm{C}>\mathrm{T}$ polymorphism of CDKN2A in cutaneous melanoma of the vertical growth phase. Am J Pathol 2002, 161:229-237.

134. Gallagher WM, Bergin OE, Rafferty M, Kelly ZD, Nolan IM, Fox EJ, Culhane AC, McArdle L, Fraga MF, Hughes L, Currid CA, O'Mahony F, Byrne A, Murphy AA, Moss C, McDonnell S, Stallings RL, Plumb JA, Esteller M, Brown R, Dervan PA, Easty DJ: Multiple markers for melanoma progression regulated by DNA methylation: insights from transcriptomic studies. Carcinogenesis 2005, 26:1856-1867.

135. Takeuchi T, Adachi Y, Sonobe H, Furihata M, Ohtsuki Y: A ubiquitin ligase, skeletrophin, is a negative regulator of melanoma invasion. Oncogene 2006, 25:7059-7069.

136. Worm J, Christensen C, Gronbaek K, Tulchinsky E, Guldberg P: Genetic and epigenetic alterations of the APC gene in malignant melanoma. Oncogene 2004, 23:5215-5226.

137. Lin YC, You L, Xu Z, He B, Yang CT, Chen JK, Mikami I, Clement G, Shi Y, Kuchenbecker K, Okamoto J, Kashani-Sabet M, Jablons DM: Wnt inhibitory factor-1 gene transfer inhibits melanoma cell growth. Hum Gene Ther 2007, 18:379-386.

138. Furuta J, Nobeyama Y, Umebayashi Y, Otsuka F, Kikuchi K, Ushijima T: Silencing of Peroxiredoxin 2 and aberrant methylation of $33 \mathrm{CpG}$ islands in putative promoter regions in human malignant melanomas. Cancer Res 2006, 66:6080-6086.

139. Kohonen-Corish MR, Cooper WA, Saab J, Thompson JF, Trent RJ, Millward MJ: Promoter hypermethylation of the O(6)-methylguanine DNA methyltransferase gene and microsatellite instability in metastatic melanoma. J Invest Dermatol 2006, 126:167-171.

140. Grunau C, Sanchez C, Ehrlich M, van der BP, Hindermann W, Rodriguez C, Krieger S, Dubeau L, Fiala E, De SA: Frequent DNA hypomethylation of human juxtacentromeric BAGE loci in cancer. Genes Chromosomes Cancer 2005, 43:11-24.

141. Mori T, Kim J, Yamano T, Takeuchi H, Huang S, Umetani N, Koyanagi K, Hoon DS: Epigenetic up-regulation of C-C chemokine receptor 7 and C$\mathrm{X}-\mathrm{C}$ chemokine receptor 4 expression in melanoma cells. Cancer Res 2005, 65:1800-1807.

142. McGuinness C, Wesley UV: Dipeptidyl peptidase IV (DPPIV), a candidate tumor suppressor gene in melanomas is silenced by promoter methylation. Front Biosci 2008, 13:2435-2443.

143. Denk AE, Bettstetter M, Wild PJ, Hoek K, Bataille F, Dietmaier W, Bosserhoff AK: Loss of maspin expression contributes to a more invasive potential in malignant melanoma. Pigment Cell Res 2007, 20:112-119.

144. Wada K, Maesawa C, Akasaka T, Masuda T: Aberrant expression of the maspin gene associated with epigenetic modification in melanoma cells. J Invest Dermatol 2004, 122:805-811.

145. Nobeyama Y, Okochi-Takada E, Furuta J, Miyagi Y, Kikuchi K, Yamamoto A, Nakanishi Y, Nakagawa H, Ushijima T: Silencing of tissue factor pathway inhibitor-2 gene in malignant melanomas. Int J Cancer 2007, 121:301-307.

146. Furuta J, Kaneda A, Umebayashi Y, Otsuka F, Sugimura T, Ushijima T: Silencing of the thrombomodulin gene in human malignant melanoma. Melanoma Res 2005, 15:15-20.

147. Mirmohammadsadegh A, Marini A, Nambiar S, Hassan M, Tannapfel A, Ruzicka T, Hengge UR: Epigenetic silencing of the PTEN gene in melanoma. Cancer Res 2006, 66:6546-6552.

148. Tokita T, Maesawa C, Kimura T, Kotani K, Takahashi K, Akasaka T, Masuda T: Methylation status of the SOCS3 gene in human malignant melanomas. Int J Oncol 2007, 30:689-694.

149. Cheng E, Trombetta SE, Kovacs D, Beech RD, Ariyan S, Reyes-Mugica M, McNiff JM, Narayan D, Kluger HM, Picardo M, Halaban R: Rab33A: 
characterization, expression, and suppression by epigenetic modification. J Invest Dermatol 2006, 126:2257-2271.

150. Kitago M, Martinez SR, Nakamura T, Sim MS, Hoon DS: Regulation of RUNX3 tumor suppressor gene expression in cutaneous melanoma. Clin Cancer Res 2009, 15:2988-2994.

151. Zhang XD, Gillespie SK, Borrow JM, Hersey P: The histone deacetylase inhibitor suberic bishydroxamate: a potential sensitizer of melanoma to TNF-related apoptosis-inducing ligand (TRAIL) induced apoptosis. Biochem Pharmacol 2003, 66:1537-1545.

152. Facchetti F, Previdi S, Ballarini M, Minucci S, Perego P, La Porta CA: Modulation of pro- and anti-apoptotic factors in human melanoma cells exposed to histone deacetylase inhibitors. Apoptosis 2004, 9:573-582.

153. Bandyopadhyay D, Okan NA, Bales E, Nascimento L, Cole PA, Medrano EE: Down-regulation of $\mathrm{p} 300 / \mathrm{CBP}$ histone acetyltransferase activates a senescence checkpoint in human melanocytes. Cancer Res 2002, 62:6231-6239.

154. Kahnberg P, Lucke AJ, Glenn MP, Boyle GM, Tyndall JD, Parsons PG, Fairlie DP: Design, synthesis, potency, and cytoselectivity of anticancer agents derived by parallel synthesis from alpha-aminosuberic acid. Med Chem 2006, 49:7611-7622.

155. Holsken A, Eyupoglu IY, Lueders M, Trankle C, Dieckmann D, Buslei R, Hahnen E, Blumcke I, Siebzehnrubl FA: Ex vivo therapy of malignant melanomas transplanted into organotypic brain slice cultures using inhibitors of histone deacetylases. Acta Neuropathol 2006, 112:205-215.

156. Vozza A, Borriello A, Criniti V, Vozza G, Della RF: New established melanoma cell lines: genetic and biochemical characterization of cell division cycle. J Eur Acad Dermatol Venereol 2003, 17:37-41.

157. Demary K, Wong L, Spanjaard RA: Effects of retinoic acid and sodium butyrate on gene expression, histone acetylation and inhibition of proliferation of melanoma cells. Cancer Lett 2001, 163:103-107.

158. Kim SH, Ahn S, Han JW, Lee HW, Lee HY, Lee YW, Kim MR, Kim KW, Kim WB, Hong S: Apicidin is a histone deacetylase inhibitor with anti-invasive and anti-angiogenic potentials. Biochem Biophys Res Commun 2004, 315:964-970.

159. Lacreusette A, Nguyen JM, Pandolfino MC, Khammari A, Dreno B, Jacques $Y$, Godard A, Blanchard F: Loss of oncostatin M receptor beta in metastatic melanoma cells. Oncogene 2007, 26:881-892.

160. Kobayashi Y, Ohtsuki M, Murakami T, Kobayashi T, Sutheesophon K, Kitayama H, Kano Y, Kusano E, Nakagawa H, Furukawa Y: Histone deacetylase inhibitor FK228 suppresses the Ras-MAP kinase signaling pathway by upregulating Rap1 and induces apoptosis in malignant melanoma. Oncogene 2006, 25:512-524.

161. Chen J, Feilotter HE, Pare GC, Zhang X, Pemberton JG, Garady C, Lai D, Yang X, Tron VA: MicroRNA-193b represses cell proliferation and regulates cyclin D1 in melanoma. Am J Pathol 2010, 176:2520-2529.

doi: 10.1186/1479-5876-8-56

Cite this article as: Sigalotti et al., Epigenetics of human cutaneous melanoma: setting the stage for new therapeutic strategies Journal of Translational Medicine 2010, 8:56

\section{Submit your next manuscript to BioMed Central} and take full advantage of:

- Convenient online submission

- Thorough peer review

- No space constraints or color figure charges

- Immediate publication on acceptance

- Inclusion in PubMed, CAS, Scopus and Google Scholar

- Research which is freely available for redistribution

Submit your manuscript at www.biomedcentral.com/submit
C Biomed Central 